\title{
BIBLIOGRAFIJA GLASBENOPEDAGOŠKEGA ZBORNIKA \\ AKADEMIJE ZA GLASBO V LJUBLJANI \\ I995-20I9
}

\author{
BRANKA ROTAR PANCE \\ Univerza v Ljubljani, Akademija za glasbo \\ branka.rotar-pance@ag.uni-lj.si
}

$\mathrm{R}$ evija Glasbeno-pedagoški zbornik Akademije za glasbo v Ljubljani je začela izhajati l. $1995 \mathrm{z}$ namenom, da mladim raziskovalcem $s$ področja glasbene pedagogike, vključenim v znanstveni magistrski in doktorski študijski program, omogoča objave v domači publikaciji. Pobudnik izdajanja prve in do zdaj edine slovenske znanstvene revije s področja glasbene pedagogike ter prvi urednik je bil Primož Kuret, ki si je vsa leta svojega delovanja na Akademiji za glasbo prizadeval za razvoj ustanove na znanstvenem področju. Že od začetka izhajanja so bili k objavam znanstvenih prispevkov povabljeni tuji in domači znanstveniki, ki so v reviji objavljali prispevke z matičnega področja ter področij, povezanih z glasbeno pedagogiko: muzikologijo, glasbeno teorijo, glasbeno estetiko, psihologijo glasbe, drugih glasbenih in pedagoških ved. Leta 2014 je bila v naslovu revije odstranjena slovnična pomanjkljivost in dodan naslov v angleškem jeziku: Glasbenopedagoški zbornik Akademije za glasbo $v$ Ljubljani/The Journal of Music Education of the Academy of Music in Ljubljana. S tem je revija poudarila svojo mednarodno dimenzijo, ki se je v letih izhajanja izražala v objavah prispevkov v tujem jeziku (v angleščini in $\mathrm{v}$ nemščini), širjenju uredniškega odbora s člani s tujih visokošolskih ustanov, ustreznih recenzentskih postopkih (dvojno slepo recenziranje), indeksiranosti v bibliografskih bazah RILM, EBSCO, ProQuest in COBISS, zapisu in upoštevanju etičnih standardov o objavljanju in dostopnosti vseh potrebnih informacij v ločenem razdelku spletne strani izdajateljice UL Akademije za glasbo. V vseh petindvajsetih letih izhajanja je bil vsak zvezek izdan v tiskani obliki. V letu 2019 je 3I. zvezek revije izšel še v elektronski obliki.

Poleg prvega urednika revije Primoža Kureta (I995-I, 2000-3, 2002-4) so revijo urejale še urednice Breda Oblak (1997-2), Darja Koter (2005-5, 20066, 2007-8, 2008-9, 2009-II, 2010-I3, 201I-I5, 2012-I7, 2013-I8, 2014-21, 2015-22, 2018-29), Branka Rotar Pance (odgovorna urednica 2000-3, 2002-4, urednica 2006-7, 2008-IO, 2009-I2, 2010-I 4, 20II-I6, 2013-I9, 2014-20, 2015-23, 201624, 2016-25, 2017-26, 2017-27, 2019-31) in Katarina Habe (2018-28, 2019-30). Po letu 2014 je kot asistentka uredništva pri izdajanju revije pomembno tehnično prispevala Tina Bohak Adam.

V prvih letih izhajanja revije so bili med posameznimi izdanimi zvezki različni časovni intervali, ki so bili v največji meri povezani s finančnimi težavami izdajatelja. Z letom 2008 pa sta vsako leto začela izhajati dva zvezka revije, 
in sicer kot netematski ali pa kot tematski zvezek. Do leta 2020 je izšlo 17 netematskih in 14 tematskih zvezkov revije; tematski so bili naslednji:

6. zvezek (2006): Vilko Ukmar Igos-IggI

8. zvezek (2007): Janko Ravnik I89I-Ig82

9. zvezek (2008): Matija Bravničar I897-1977

II. zvezek (2009): Pavel Šivic (Igo8-1995)

I3. zvezek (2010): Radovan Gobec (Igog-1995)

I5. zvezek (2011): Marijan Lipovšek (I9I0-1995)

17. zvezek (2012): Zvonimir Ciglič (Ig2I-2006)

18. zvezek (2013): Bojan Adamič (1912-1995)

21. zvezek (2014): Samo Vremšak (1930-2004)

22. zvezek (2015): Primož Kuret. Ambasador slovenske kulture

25. zvezek (2016): Javno glasbeno šolstvo na Slovenskem. Pogledi ob zoo-letnici. 27. zvezek (2017): Breda Oblak. Utemeljiteljica didaktike glasbe na Slovenskem 29. zvezek (2018): Jakob Jezz (1928-). Tokovi sodobne zborovske glasbe

31. zvezek (2019): Mostovi med formalnim in neformalnim glasbenim izobraževanjem.

Štirje zvezki revije so bili izdani s posvetilom, in sicer:

2. zvezek (1997), posvečen 6o-letnici Primoža Kureta,

4. zvezek (2002), posvečen Bredi Oblak ob njenem življenjskem jubileju,

5. zvezek (2005), posvečen Primožu Kuretu ob njegovi sedemdesetletnici,

22. zvezek (2015), posvečen 8o-letnici Primoža Kureta. V tem zvezku so bili s pridobljenimi dovoljenji objavljeni ponatisi jubilantovih znanstvenih razprav, objavljeni v različnih tujih znanstvenih publikacijah v nemškem jeziku v letih 1989-2013.

Jubilej - petindvajsetletnica izdajanja revije - nas je spodbudil k pripravi bibliografije vseh objavljenih prispevkov. V skladu z bibliografskimi standardi smo jo oblikovali v treh sklopih:

I. Sezami besedil po avtorjih

I.I Članki

I.2 Povzetki magistrskih del in doktorskih disertacij

I.3 Druga besedila

2. Kronološki seznam objavljenih zvezkov

3. Imensko in stvarno vsebinsko kazalo

3.I Imensko vsebinsko kazalo

3.2 Stvarno vsebinsko kazalo.

Pri pripravi bibliografije smo prevzeli standardni model, ki ga je uporabil Zoran Krstulović iz Narodne in univerzitetne knjižnice Ljubljana pri pripravi bibliografije Muzikološkega zbornika 1965-20I4. Prevzeti vzorec vključuje: priimek in ime avtorja/-ev; naslov, prevod naslova ( $v$ izdajah zvezkov, ki so prevode naslovov vsebovali), navedbe letnice, številke in strani zvezka. Abecedni 
vrstni red je kot načelo razvrščanja upoštevan v I. in 3. sklopu, v 2. sklopu pa upoštevamo kronološko načelo razvrščanja izdanih zvezkov. Z željo po mednarodni uporabi bibliografije smo vsebinske oznake zapisali tudi v angleščini.

Zoranu Krstuloviću se iskreno zahvaljujemo za vso pomoč in nasvete ter zbrane in poslane Cobissove bibliografske zapise vseh evidentiranih objavljenih prispevkov in izdaj posameznih zvezkov revije.

I. SEZNAMI BESEDIL PO AVTORJIH

I.I Članki

Ačić, Gordana

Milena Petrović, Gordana Ačić in Vera Milanković: Svobodne asociacije glasbenikov na dane glasbene koncepte. Musicians' free associations on the given music concepts. 2017, 26, 49-6I.

Ajtnik, Milka

Uveljavljene aplikacije poslušanja glasbe v splošnem izobraževanju. 2000, 3, $67-77$.

Andraschke, Peter

„Du sollst nicht, du mußt." Struktur und Textbehandlund in Schönbergs

Chören op. 27 nr. I und 2. 2005, 5, 37-52.

Antoni, Luisa

Uredniško delo Matija Bravničarja. Matija Bravničar’s Editorial Work. 2008, 9, 33-45.

Raznolikost in bogastvo glasbenega šolanja na Primorskem. The diversity and wealth of musical education in Primorska region. 2016, 25, 287-296.

Avsenak Pogačnik, Meri

Šanson Bojana Adamiča in Jugoslovanski šanson - Rogaška. Bojan Adamič’s chanson and festival Yugoslavian Chanson - Rogaška. 2013, I8, 169-188.

Bačlija Susić, Blaženka

Različni metodični pristopi pri pouku klavirja in storilnostna motivacija učencev. Various teaching methods in piano learning and student's achievement motivation. 2010, 14, 29-52.

Bagarič, Alenka

Seznam glasbenih del Marijana Lipovška. Bibliography of Marijan Lipovšek. 20II, I5, I8I-217. 


\section{Barbarić, Sara \\ Snježana Dobrota in Sara Barbarić: Stališča hrvaških osnovnošolcev do glasbenega pouka. Croatian elementary school students' attitudes towards music lessons. 2017, 26, 5-19.}

\section{Barbo, Matjaž}

Prispevek k orisu življenja in dela F. J. B. Dusíka. 2005, 5, 53-68.

Pavel Šivic in Collegium musicum. Pavel Šivic and the Collegium Musicum. 2009, II, 37-52.

Iz komornega opusa Marijana Lipovška. From Marijan Lipovšek’s chamber works. 2011, I5, 99-II6.

Sožitje vokala in instrumentala v kantatah Jakoba Ježa. Coexistence of vocal and instrumental paradigms in cantatas of Jakob Jež. 20I8, 29, 6I-72.

\section{Bergant, Hubert}

Hommage a Primož Kuret: mož, ki mu je uspela sinteza umetnostne zgodovine in muzikologije. 1997, 2, 9-22.

\section{Bernhofer, Andreas}

Herausforderungen und Entwicklungsfelder des österreichischen Musikschulwesens. Challenges and development potentials of the Austrian music school system. 2016, 25, 297-304.

\section{Beuermann, Dimitrij}

Leon Stefanija, Matej Bonin, Dimitrij Beuermann in Ada Holcar Brunauer: O koristi in škodi teorije glasbe v glasbenem izobraževanju na osnovnih in glasbenih šolah. Advantages and disadvantages of music theory in music education in primary and music school. 2016, 25, 203-2016.

Celostna glasbena šola. The holistic music school. 2016, 25, 317-338.

\section{Biffio, Gesa}

Nove razširitve lepega tona na violončelu. New extensions of the beautiful cello tone. 2011, I6, 77-107.

\section{Bizjak, Marina}

Marina Bizjak in Patrick K. Freer: Ali se zavedamo pomena vokalne tehnike $\mathrm{v}$ adolescenci? Do we realize the importance of vocal technique in adolescence? 2015, 23, 39-48.

Pedagoški pristopi pri poučevanju petja v času glasovnih sprememb. Pedagogical approaches for teaching singing at the time of voice change. 2017, 27, 201-206.

\section{Blašković, Jelena}

Glasbeni profil študentov predšolske vzgoje glede na njihovo predhodno izobraževanje. Understanding the early childhood education students' 
musical profile with regard to their educational background. 2014, 20, 5I-70.

Učinki pevskega izobraževanja na nekatere glasbene dosežke študentov predšolske vzgoje. The effect of singing education on some preschool education students' music achievements. 2015, 23, 17-37.

Jelena Blašković in Tihomir Prša: Izkušnje in odnos osnovnošolcev do gregorijanskega petja. Experience and attitude of primary school students towards Gregorian singing. 2017, 27, 133-I 44.

\section{Bogunović Hočevar, Katarina}

Fragment k zvrsti klavirske miniature - njen »pravi« začetek v slovenski glasbeni literaturi? Exploring the piano miniature genre - Its "real" beginnings in Slovene music? 2007, 8, 67-79.

Pavel Šivic in operna kritika. Pavel Šivic and his operatic criticism. 2009, II, I43-I52.

\section{Bohak, Tina}

Profil igralca (pevca) na Slovenskem od konca i9. stoletja do druge svetovne vojne. Actor's (singer's) profile in Slovenia from the late $19^{\text {th }}$ century to the World War II. 2011, 16, 57-75.

Nova spoznanja o življenju in delovanju pevca in pedagoga Julija Betetta (1885-1963). New facts about the life and work of opera singer and teacher Julij Betetto (1885-1963). 2013, 19, 75-94.

Solistična poustvarjalnost baritonista Sama Vremšaka. Solo career of baritone Samo Vremšak. 201 4, 21, 33-49.

Miloš Brišnik - pozabljen mariborski pevski pedagog. Miloš Brišnik - The forgotten Maribor singing educator. 2016, 24, 29-43.

Solopevska pedagogika na glasbeni šoli društva Glasbena matica od začetkov do ustanovitve konservatorija (I882-1919). Solo singing pedagogy in Glasbena matica music school from its beginnings to establishment of conservatory (1882-1919). 2016, 25, 57-73.

»Hočem postati pevka« - življenjska in ustvarjalna pot koncertne pevke, altistke Marije Bitenc Samec. "I want to become a singer" - The life and creative path of the concert singer, alto Marija Bitenc Samec. 2017, 26, 63-78.

Breda Oblak - spiritus agens seminarskega izobraževanja glasbenih pedagogov »Glasbeni Bovec «. Breda Oblak - Spiritus agens of the seminar education of music pedagogues, named "Glasbeni Bovec". 2017, $27,65-75$.

\section{Bohak Adam, Tina}

»En, ten, tenera« - Ježevi otroški in mladinski zbori v Grlici. “En, ten, tenera" - Children's and youth choirs of Jakob Jež. 2018, 29, 17-33. 


\section{Bonin, Matej}

Leon Stefanija, Matej Bonin, Dimitrij Beuermann in Ada Holcar Brunauer: O koristi in škodi teorije glasbe v glasbenem izobraževanju na osnovnih in glasbenih šolah. Advantages and disadvantages of music theory in music education in primary and music school. 2016, 25, 203-216.

\section{Borota, Bogdana}

Računalniško okolje ter glasbeni čas v igri in slikovnem zapisu. Computer environment and musical time in play and image format. 2006, 7, 83IO4.

Dokumentacija v vlogi spremljanja glasbenega razvoja otroka.

Documentation as a part of the assessment of music development. 2009, I2, 5-19.

Verica Janeva in Bogdana Borota: Nekateri izzivi izobraževanja opernih pevcev v Italiji. Some of the challenges of education opera singers in Italy. 2014, 20, 113-127.

Didaktične zbirke za glasbeno vzgojo Brede Oblak z diahrone perspective. Didactic sets by Breda Oblak from a diachronic perspective. 2017, 27, $29-48$.

Bogdana Borota in Tina Štemberger: Glasbene zmožnosti in potrebe po izobraževanju študentov predšolske vzgoje. Musical abilities in relation to the needs to educate preschool education students. 2019, 31, 37-56.

\section{Brusniak, Friedhelm}

Glasbena pedagogika/izobraževanje, quo vadis? Impulzi za razpravo o glasbeni pedagogiki/izobraževanju s perspektive Karla Heinricha Ehrenfortha. Music pedagogy/education, quo vadis? Impulses for a discussion about music pedagogy/education from the perspective of Karl Heinrich Ehrenforth. 2015, 23, 73-77.

\section{Cencič, Majda}

Tina Štemberger in Majda Cencič: Pomen ustvarjalnosti vzgojiteljev s poudarkom na glasbeni ustvarjalnosti. The importance of preschool teachers' creativity with an emphasis on musical creativity. 2015, 23, 5-16.

\section{Cigoj Krstulović, Nataša}

Glasbena matica, ljudska pesem in percepcija glasbe na Slovenskem v drugi polovici 19. stoletja. 2005, 5, 69-82.

Načela in podobe slovenskega javnega glasbenega izobraževanja: primer šole in konservatorija ljubljanske Glasbene matice (1882-1926). Principles and forms of Slovenian public music education: The case of Glasbena matica music school and conservatory in Ljubljana (1882-1926). 2016, 25, $4 \mathrm{I}-55$. 
Glasba kot virtualna izraznost. Music as virtual expression. 2017, 27, 95-102.

Cvetković Crvenica, Jelena

Jelena Cvetković Crvenica in Milica Jovanović: Ocena akreditiranega profesionalnega programa usposabljanja na področju solfeggio v Srbiji 20II-2019. Evaluation of the accredited professional training program in the field of solfeggio in Serbia 2011-2019. 2019, 30, 31-55.

\section{Čorić, Ana}

Razvoj skupnostnih glasbenih dejavnostih v visokošolskem izobraževanju: delo na ozvočenih zgodbah. Developing community music activities in higher education system: Working on sounded stories. 2019, 31, 17-35.

\section{Debevc, Matjaž}

Jernej Weiss, Tjaša Ribizel, Ines Kožuh in Matjaž Debevc: MySolfeggio: mobilna in tablična aplikacija za učenje solfeggia. MySolfeggio: Mobile and tablet application for learning of solfeggio. 2017, 27, 21-32.

\section{Dekleva, Igor}

Prispevek k mozaiku srečanj dveh dežel: stiki med Slovenijo in Avstrijo. 1997, 2, 23-36.

»Poslušaj pojoči zven klavirja«: Janko Ravnik - klavirski pedagog. "Listen to the singing sound of the piano": Janko Ravnik as piano teacher. 2007 , $8,45-56$.

\section{Denac, Olga}

Glasbena vzgoja in celostni razvoj otrokove osebnosti. 2000, 3, 7-I9.

Estetska vzgoja in načrtovanje učnega procesa glasbene vzgoje. 2002, 4, 3338.

Kurikulum za vrtce in načrtovanje glasbene vzgoje. 2005, 5, 83-94.

Uresničevanje kurikuluma za vrtce v procesu operativnega načrtovanja glasbene vzgoje. Realizing of the curriculum for kindergartens in the process of operative planning of music education. 2006, 7, 105-I23.

Olga Denac in Helena Vargazon: Vpliv institucionalne glasbene vzgoje na raven razvitosti melodičnega in ritmičnega posluha 5-6 let starih otrok. The effects of institutional music education on the level of melodic and rhytmic abilities development in 5-6 year olds. 2017, 27, 163-174.

\section{Dernjančević, Zdravko}

Slavonski folklorni napevi z vidika tonskih nizov. Slavonian folk tunes from the aspect of tone lines. 2011, 16, 109-II8. 


\section{Dobrota, Snježana}

Snježana Dobrota in Sara Barbarić: Stališča hrvaških osnovnošolcev do glasbenega pouka. Croatian elementary school students' attitudes towards music lessons. 2017, 26, 5-19.

Snježana Dobrota in Ivana Senjan: Vpliv modela recipročne povratne informacije glasbenega odziva na oblikovanje glasbenega okusa učencev. The impact of the reciprocal feedback model of musical response on shaping music taste of students. $2018,28,5-28$.

\section{de Vugt, Adri}

Franz Niermann, Sarah Hennessy, Adri de Vugt in Isolde Malmberg: Projekt meNet in učni izidi pri izobraževanju učiteljev glasbe. The meNet project and the Learning Outcomes in music teacher training. 2008, I0, 7-24.

\section{Faganel, Tomaž}

Med zbori ad aequales Janka Ravnika. Janko Ravnik's ad aequales choral works. 2007, 8, 9I-IIO.

\section{Flisar Šauperl, Manja}

Glasbena matica Maribor z vidika glasbenega izobraževanja. Glasbena Matica Maribor from the perspective of music education. 2016, 25, 75IO2.

\section{Florjanc, Ivan}

Komorna glasba Vilka Ukmarja. The chamber music of Vilko Ukmar. 2006, 6, 8I-IOI.

Skladbe sakralne narave Janka Ravnika. The sacred works of Janko Ravnik. $2007,8,123-145$.

Simfonija »Sentence« - Šivičeva četrta simfonija? The "Sentences" symphony: Šivic >s fourth symphony? 2009, II, I67-182.

Orkestralna dela Marijana Lipovška - bibliografski popis in oris. Orchestral works by Marijan Lipovšek - Bibliographic list and outline. 201 I, I5, I55-179.

Orkestralna dela Zvonimirja Cigliča. Orchestral works of Zvonimir Ciglič. 2012, $17,31-54$.

Orkestralna dela Sama Vremšaka. Orchestral works by Samo Vremšak. 2or 4, 2I, I37-I66.

Harmonija - traktati in učbeniki v slovenščini. Premislek ob $200-l e t n i c i$ javnega glasbenega šolstva v Sloveniji. Harmony - Treatises and textbooks in Slovenian. reflection UPON the $200^{\text {th }}$ anniversary of public music education in Slovenia. 2016, 25, 149-178. 
Frantar, Vladimir

Popevka in Bojan Adamič. Bojan Adamič and popular songs. 2013, I8, I5II68.

\section{Freer, Patrick K.}

Marina Bizjak in Patrick K. Freer: Ali se zavedamo pomena vokalne tehnike $\mathrm{v}$ adolescenci? Do we realize the importance of vocal technique in adolescence? 2015, 23, 39-48.

\section{Gabrič, Aleš}

Pevski zbori med tradicijo, revolucionarno normo in internacionalo. Choirs between the tradition, revolutionary standard and the internationale. 2010, $13,43-63$.

\section{Girdzijauskiené, Rūta}

Kreativno izražanje osnovnošolskih otrok pri petju. Primary school children's creative expression in singing. 2016, 24, 45-55.

Sandra Rimkutè-Jankuvienè in Rūta Girdzijauskienė: Kompetence učiteljev glasbe za spodbujanje glasbene ustvarjalnosti učencev s pomočjo MCT. Music teacher's competences to foster pupils' musical creativity through MCT. 2018, 28, 79-93.

\section{Gobec, Mitja}

Radovan Gobec - moj profesor in vzornik. Radovan Gobec - my professor and my idol. 2010, 13, 27-34.

\section{Golobič, Špela}

Odziv učiteljev in učencev na simfonično matinejo Glasbene mladine Slovenije. The response of teachers and pupils to a Musical Youth of Slovenia's symphony matinee. 2014, 20, 71-92.

Kulturna vzgoja na področju glasbene umetnosti v osrednjih slovenskih glasbenih institucijah. Cultural education in the field of music in Slovenian principal musical foundations. 2019, 31, I45-160.

\section{Gortan-Carlin, Ivana Paula}

Ivana Paula Gortan-Carlin in Lorena Lazarić: Regionalna kulturna ozaveščenost študentov edukacijskih ved s posebnim poudarkom na regionalni glasbi Istre. Regional cultural awareness of educational sciences students with a special review of the Istrian regional music. 2017, 27, II7- I3I.

\section{Haas, Miha}

Tonske barve na klavirju: akustična predispozicija ali kontekstualna iluzija? Piano Timbre: Acoustic predisposition or contextual illusion? 2016, 24, 87-102. 


\section{Habe, Katarina}

Katarina Habe in Ana Smolnikar: Dejavniki oblikovanja glasbene samopodobe učencev, ki obiskujejo glasbeno šolo. Factors that influence musical self-image in pupils who attend music schools. 2016, 25, 255-268.

Katarina Habe in Vida Kržič: Doživljanje izvajalske anksioznosti učencev glasbene šole v zgodnjem mladostništvu. Experiencing performance anxiety in music school pupils in early adolescence. $2017,26,33-48$.

Osebnostne vrline in občutek poslanstva glasbenih pedagogov - temelj uspešne poklicne kariere glasbenega pedagoga. Character virtues and experiencing profession as a calling in music educators - A core of succesful music teaching. 2017, 27, 77-93.

Študentski inovativni projekti (ŠIPK) - oblika neformalnega pridobivanja poklicnih kompetenc na visokošolski ravni. Students' inovative projects (ŠIPK) - A form of non-formal acquisition of professional competences at higher education. 2019, 31, 5-15.

\section{Hennessy, Sarah}

Franz Niermann, Sarah Hennessy, Adri de Vugt in Isolde Malmberg: Projekt meNet in učni izidi pri izobraževanju učiteljev glasbe. The meNet project and the learning outcomes in music teacher training. 2008, 10, 7-24.

\section{Holcar Brunauer, Ada}

Urban Kordeš, Barbara Sicherl-Kafol in Ada Holcar Brunauer: Model formativnega spremljanja znanja pri glasbeni vzgoji. A model of formative assessment in music education. 2013, 19, 5-22.

Leon Stefanija, Matej Bonin, Dimitrij Beuermann in Ada Holcar Brunauer: O koristi in škodi teorije glasbe v glasbenem izobraževanju na osnovnih in glasbenih šolah. Advantages and disadvantages of music theory in music education in primary and music school. 2016, 25, 203-216.

Ivec, Anja

Pomen motivacije v projektu $\gg$ Dijaki komponisti $\ll$ Konservatorija Maribor.

The meaning of motivation in the student composer project at

Conservatory Maribor. 2017, 27, 191-199.

Glasbena revija kot učilo: Mlada Sloga, glasilo glasbene šole Sloga v Ljubljani. Music magazine as a teaching aid: Mlada Sloga, publication of the Sloga Music School in Ljubljana. 2019, 31, 169-180.

\section{Janeva, Verica}

Verica Janeva in Bogdana Borota: Nekateri izzivi izobraževanja opernih pevcev v Italiji. Some of the challenges of education opera singers in Italy. 20I4, 20, II3-I 27. 
Jovanović, Milica

Jelena Cvetković Crvenica in Milica Jovanović: Ocena akreditiranega profesionalnega programa usposabljanja na področju solfeggio v Srbiji 2011-2019. Evaluation of the accredited professional training program in the field of solfeggio in Serbia 201I-2019. 2019, 30, 31-55.

\section{Jukić, Renata}

Tihana Škojo in Renata Jukić: Ocenjevanje pedagoških kompetenc učiteljev solfeggia. The assessment of pedagogical competences of solfeggio teachers. 2019, 31, 69-8I.

\section{Kavčič Pucihar, Ana}

Učiteljeve strategije poučevanja pri individualnem inštrumentalnem pouku flavte v glasbenih šolah. Teaching strategies in individual instrumental flute instruction in music schools. 2019, 30, 5-29.

\section{Kiš Žuvela, Sanja}

Ko se nepremični (fiksni) »DO « začne premikati: večpomenskost intonančnih zlogov. When fixed "DO" tends to move: The ambiguity of the solfège syllabary. 2018, 28, 29-49.

\section{Kolman, Kristijan}

Kristian Kolman in Jože Rugelj: Inovativni pristop k poučevanju violine na osnovi kognitivne teorije učenja $\mathrm{z}$ večpredstavnostjo. Innovative approach to teachning violin based on the cognitive theory of multimedia learning. 2019, 31, 83-99.

\section{Kordeš, Urban}

Urban Kordeš, Barbara Sicherl-Kafol in Ada Holcar Brunauer: Model formativnega spremljanja znanja pri glasbeni vzgoji. A model of formative assessment in music education. 2013, 19, 5-22.

\section{Košta, Tomislav}

Smiljana Zrilić in Tomislav Košta: Možnosti implementacije Hrvaškega nacionalnega izobraževalnega standarda $\mathrm{v}$ pouk glasbe za otroke $s$ posebnimi potrebami. The possibilities of implementing the Croatian national education standard in teaching music to pupils with special educational needs. 2008, 10, 72-84.

Razvoj predmeta petje v osnovnošolskih programih Hrvaške in Slovenije v obdobju med svetovnima vojnama. Development of singing lessons in elementary school curricula in Croatia and Slovenia in interwar period. 2010, I4, 7I-88.

\section{Koter, Darja}

Čembalo na slovenskih in istrskih freskah. 1997, 2, 37-47. 
Hinko Druzovič - pedagog in čitalničar na Ptuju. 2002, 4, 39-48.

Bibliografija Primoža Kureta. 2005, 5, II-33.

Ljubljanska Opera pod vodstvom Vilka Ukmarja (1939-1945). The Ljubljana Opera under

Vilko Ukmar. 2006, 6, 35-48.

$\gg$ Ljubljanska pianistična šola«. Janko Ravnik - utemeljitelj slovenske pianistične šole. "The Ljubljana piano-school". Janko Ravnik - the founder of the Slovene piano school. 2007, 8, 3I-43.

Matija (Frane) Bravničar - prispevek k biografiji. Towards a Bigraphy of Matija (Frane) Bravničar. 2008, 9, 7-24.

Radovan Gobec - življenjska in ustvarjalna pot. Radovan Gobec's life and career. 2010, 13, 7-25.

Portretna skica Marijana Lipovška - čas mladosti in zorenja. An Outline of Marijan Lipovšek - his youth and maturing. 201I, I5, 7-28.

Zvonimir Ciglič: med recepcijo in avtorefleksijo. Zvonimir Ciglič: between reception and self-reflection. 2012, 17, $103-116$.

Bojan Adamič: the correlation between his creative and performing life. $2013,18,5-21$.

Bojan Adamič: soodvisnost njegovega umetniškega in poustvarjalnega delovanja. 2013, I8, 23-35.

Vzgojno-izobraževalno in kulturno poslanstvo ljubljanske Glasbene matice in Glasbene akademije v letih 1939-1945. The educational and cultural mission of the Glasbena matica Ljubljana music society and Academy of Music 1939 to $1945.2013,19,61-74$.

Samo Vremšak: Artist and pedagogue. 20I4, 21, 5-20.

Umetnik in pedagog Samo Vremšak. 20I4, 2I, 2I-3I.

Vloga ljubljanskega Dramatičnega društva pri glasbeno-gledališkem izobraževanju v obdobju od I869 do I877. The role of Ljubljana Dramatic Society at the music theatre education in the period 1869 to I877. 2016, 25, 25-40.

Vpliv Jurčeta Vrežeta na razvoj mladinskih pevskih zborov na Štajerskem. The influence of Jurče Vreže on the development of youth choirs in Styria. 2017, 27, 103-II5.

Jakob Jež - glasbeni samohodec. Jakob Jež - Musical maverick. 20r8, 29, 5-16.

\section{Koren, Danaja}

Katarina Zadnik in Danaja Koren: Montessori pedagogika in njena vloga pri nauku o glasbi v glasbeni šoli. Montessori pedagogy and its role in music theory in music school. 2017, 27, 175-190. 


\section{Kovačič, Mojca}

Rastemo z opero: neformalno glasbeno izobraževanje mladostnikov in razvoj kompetenc. Growth through opera: Non-formal music education for youngsters and the development of competencies. 2019, 31, 133-I 44.

\section{Kožuh, Ines}

Jernej Weiss, Tjaša Ribizel, Ines Kožuh in Matjaž Debevc: MySolfeggio: mobilna in tablična aplikacija za učenje solfeggia. MySolfeggio: Mobile and tablet application for learning of solfeggio. 2017, 27, 21-32.

\section{Križnar, Franc}

Zgodovinski pogled na interval kvarto in kvinto s posamičnimi poudarki $\mathrm{v}$ slovenski glasbi 20. stoletja. 2002, 4, 56-64.

Estetika in stil Vilka Ukmarja. The aesthetics and style of Vilko Ukmar. 2006, 6, II5-I26.

Življenje in delo Zvonimirja Cigliča. Life and work of Zvonimir Ciglič. 20I2, I7, 7-30.

Glasba Bojana Adamiča v času druge svetovne vojne. Bojan Adamičss music during World War II. 2013, I8, 37-6I.

Didaktična in metodična glasbena literatura v piramidi slovenskega glasbenega šolstva v izdajah Založbe Zavoda RS za šolstvo. Didactic and methodic music literature in pyramid of Slovenian music education published by the National Education Institute. 2016, 25, 339-349.

\section{Krones, Harmunt}

Zur Geschichte des arbeiter $=$ Gesangvereines Vorwärts in Laibach. 2005, 5, 95-104.

\section{Krstulović, Zoran}

Seznam objavljenih del skladatelja Vilka Ukmarja. 2006, 6, I3I-I75.

\section{Kržič, Vida}

Katarina Habe in Vida Kržič: Doživljanje izvajalske anksioznosti učencev glasbene šole v zgodnjem mladostništvu. Experiencing performance anxiety in music school pupils in early adolescence. $2017,26,33-48$.

\section{Kuret, Primož}

Slovenska glasba po prvi svetovni vojni. Slovene music after WWI. 2007, 8, 7-I 4 .

Bravničarjeva »Srečanja in spomini «. Bravničar’s “Meetings and Reminiscences”. 2008, 9, 25-32.

Die Reisetagebücher des Paolo Santonino (I 485-I487). Popotni dnevnik Paola Santonina (1 485-I487). Ponatis objave iz 1. 1999. 2015, 22, I7-24. 
Slowenische protestantische Gesangbücher im 16. Jahrhundert. Slovenske protestantske pesmarice 16. stoletja. Ponatis objave iz 1. 2006. 2015, 22, $25-48$.

Die Rolle und die Tätigkeit der Philharmonischen Gesellschaft in Ljubljana. Delovanje in vloga Filharmonične družbe v Ljubljani. Ponatis objave iz 1 . 1990. 2015, 22, 49-59.

Der Archivalienbestand der Philharmonischen Gesellschaft in Laibach - Eine bedeutende Quelle zum slowenischen Musikleben im 19. und beginnenden 20. Jahrhundert. Arhivska zbirka Filharmonične družbe v Ljubljani - pomemben vir o glasbenem življenju na Slovenskem v 19. in na začetku 20. stoletja. Ponatis objave iz l. 2007. 2015, 22, 60-70.

Die Laibacher Philharmonische Gesellschaft und die Illyrischen Provinzen (1809-13). Ljubljanska Filharmonična družba in Ilirske province (1809I813). Ponatis objave iz 1. 1989. 2015, 22, 71-77.

Joseph Haydns Sakralwerke in Programmen der Philharmonischen Gesellschaft zu Ljubljana (Laibach). Haydnova sakralna dela na sporedih ljubljanske Filharmonične družbe. Ponatis objave iz l. 2002. 2015, 22, 78-92.

Einige erhaltene Briefe im Archiv der Philharmonischen Gesellschaft in Laibach/Ljubljana

Nekaj ohranjenih pisem v arhivu ljubljanske Filharmonične družbe. Ponatis objave iz 1. 2004. 2015, 22, 93-108.

Großes Jubiläum der Philharmonischen Gesellschaft in Ljubljana (Laibach) im Jahre 1902. Veliki jubilej ljubljanske Filharmonične družbe leta 1902. Ponatis objave iz 1. 2004. 2015, 22, 109-117.

Mozart-Rezeption in Slowenien. Recepcija Mozartovih del na Slovenskem. Ponatis objave iz l. 1997. 2015, 22, 119-124.

Johann Gottfried Herder und die Slowenen. Johann Gottfried Herder in Slovenci. Ponatis objave iz 1. 2002. 2015, 22, I25-I32.

Das Ständische Theater in Ljubljana/Laibach: über die italienischen Opernaufführungen am Ende des i8. und Anfang des 19. Jahrhunderts in Ljubljana. Stanovsko gledališče v Ljubljani: italijanske operne predstave ob koncu i8. in na začetku i9. stoletja. Ponatis objave iz l. 1999. 2015, 22, 133-I4I.

Biedermeier in Slowenien. Bidermajer na Slovenskem. Ponatis objave iz l. 2000. 2015, 22, I 42-149.

Zum Werdegang der slowenischen nationalen Musikkultur. K nastanku slovenske nacionalne glasbene kulture. Ponatis objave iz l. 1993. 2015, 22, I5O-I54.

Die geistliche Musik und die slowenische Nationalbewegung in der zweiten Hälfte des 19. Jahrhunderts. Duhovna glasba in slovensko narodno gibanje v 2. polovici 19. stoletja. Ponatis objave iz l. 1994. 2015, 22, I55I6I. 
Mahler und Ljubljana/Laibach. Mahler v Ljubljani. Ponatis objave iz 1. I989. 2015, 22, 162-169.

Laibacher Orchesterverhältnisse und Mahler Orchesterbesetzung in Laibach. Ljubljanske orkestrske razmere in Mahlerjeva zasedba orkestra v Ljubljani. Ponatis objave iz 1. 1998. 2015, 22, 170-I83.

Die slowenish-tschechischen Musikbeziehungen und Antonín Dvořák. Slovensko-češki glasbeni stiki in Antonin Dvořák. Ponatis objave iz 1 . 2007. 2015, 22, 184-190.

Ein Brief des slowenischen Komponisten Benjamin Ipavec an Leoš Janáček. Pismo slovenskega skladatelja Benjamina Ipavca Leošu Janáčku. Ponatis objave iz 1. 2001. 2015, 22, 191-195.

„Alle Landschaft ist ein Seelenzustandt...“: Hugo Wolf - seine Zeitgenossen und Nachfolger. »Vsa pokrajina je odraz duše ...«: Hugo Wolf - njegovi sodobniki in nasledniki. Ponatis objave iz 1. 2001. 2015, 22, 196-203.

Zemlinsky als Lehrer des slowenischen Komponisten Josip Ipavec. Zemlinsky - učitelj slovenskega skladatelja Josipa Ipavca. Ponatis objave iz l. 1995. 2015, 22, 204-208.

Die Arbeiterkultur in Laibach während der k. k. Monarchie. Kultura delavskega razreda v Ljubljani v času Monarhije. Ponatis objave iz 1. 1999. 2015, 22, 209-218.

Die Musik am Anfang des 20. Jahrhunderts in den Kirchen Ljubljanas. Glasba v ljubljanskih cerkvah na začetku 20. stoletja. Ponatis objave iz 1 . 2006. 2015, 22, 219-227.

Militärmusikkapellen in Ljubljana. Vojaške godbe v Ljubljani. Ponatis objave iz 1. 2004. 2015, 22, 228-235.

Deutsches Kulturschaffen in Krain vor dem Ersten Weltkrieg. Nemška kultura na Kranjskem pred prvo svetovno vojno. Ponatis objave iz 1. 1992. 2015, 22, 236-244.

Wagner in den Konzert - und Opernprogrammen vor dem Ersten Weltkrieg in Ljubljana/Laibach. Wagner na ljubljanskih koncertnih in opernih sporedih pred prvo svetovno vojno. Ponatis objave iz 1. 2013. 2015, 22, $245-253$.

Wien und Slowenien - gegenseitige Bereicherungen. Dunaj in Slovenija medsebojna obogatitev. Ponatis objave iz 1. 2009. 2015, 22, 254-267.

Sloweniens Schicksal 1918-1991: Eine kulturhistorische Skizze. Usoda Slovenije 1918-1991: kulturnozgodovinska skica. Ponatis objave iz l. 1992. 2015, 22, 268-273.

Slavko Osterc - Minutenopern. Slavko Osterc - minutne opere. Ponatis objave iz 1. 2005. 2015, 22, 274-278.

Zwei verschiedene „Pater noster“ von Slavko Osterc und Karol Pahor. Dva različna očenaša, Slavka Osterca in Karola Pahorja. Ponatis objave iz 1. 2007. 2015, 22, 279-283. 
Die Bedeutung der Musik in der slowenischen Widerstandsbewegung. Pomen glasbe v slovenskem odporniškem gibanju. Ponatis objave iz l. 2004. 2015, 22, 284-289.

Slowenische Musik der 5oer und 6oer Jahre. Slovenska glasba 50. in 60. let. Ponatis objave iz 1. 1998. 2015, 22, 290-294.

Slowenische Musik heute zwischen Staat und Markt. Slovenska glasba danes - med državo in tržiščem. Ponatis objave iz 1. 2000. 2015, 22, 295-300.

Musik als Opposition. Glasba kot opozicija. Ponatis objave iz 1. 1995. 2015, 22, $301-305$.

Das apokalyptische Jahrhundert. Apokaliptično stoletje. Ponatis objave iz l. 2000. 2015, 22, 306-311.

\section{Kuret, Stojan}

Ljudsko izročilo Slovencev v Italiji v zborovskih delih Pavleta Merkùja. Folk tradition of Slovenians in Itay in the choral works of composer Pavle Merkù. 20I8, 29, 91-I22.

\section{Lapuh, Alja}

Usvajanje glasbenega znanja in veščin pri otrocih z Aspergerjevim sindromom. Adoption of musical knowledge and skills in children with Asperger's syndrome. 2019, 30, 73-91.

\section{Lazarić, Lorena}

Ivana Paula Gortan-Carlin in Lorena Lazarić: Regionalna kulturna ozaveščenost študentov edukacijskih ved $s$ posebnim poudarkom na regionalni glasbi Istre. Regional cultural awareness of educational sciences students with a special review of the Istrian regional music. 2017, 27, II7-I3I.

\section{Lešnik, Ivan}

Kakovost pevske dejavnosti v prvem triletju osnovne sole. Singing quality in the first triennium of primary school. 2009, I2, 20-40.

\section{Lokar Lavrenčič, Vlasta}

Tamburica - od tradicionalnega inštrumenta do sodobne pedagoške prakse. Tamburitza - From a traditional instrument to modern pedagogical practice. $2011,16,43-56$.

\section{Loos, Helmut}

Das Monodram „Sophonisbe“ von Christian Gottlob Neefe. 2005, 5, I05II 4 .

\section{Malmberg, Isolde}

Franz Niermann, Isolde Malmberg in Gerhard Sammer: Mrežno povezovanje za glasbeno izobraževanje v Evropi. Aktualna tematska 
težišča EAS. Netzwerk-arbeit für musikalische bildung in Europa. Aktuelle hemenschwerpunkte der EAS. 2006, 7, 42-68.

Franz Niermann, Sarah Hennessy, Adri de Vugt in Isolde Malmberg: Projekt meNet in učni izidi pri izobraževanju učiteljev glasbe. The meNet project and the Learning Outcomes in music teacher training. 2008, 10, 7-24.

\section{Marčun, Andreja}

Pomen glasbene umetnosti v povezavi z naracijo. The importance of music in conjunction with narration. 2016, 24, 73-86.

Poučevanje učencev s posebnimi potrebami v glasbenih šolah - nekatere metode in oblike pedagoškega dela. Teaching children with special needs in music school - some methods and forms of pedagogical work. 2016, 25, 269-286.

\section{Marković, Vedrana}

Vloga in pomen urjenja posluha (solfeggio) ter aktivnih učnih procesov v začetnem obdobju glasbenega izobraževanja. Role and significance of ear training (solfeggio) and active learning processes in the innitial phase of music education. 2008, I0, 85-98.

Vpliv slovenske kulture in glasbene pedagogike na razvoj glasbenega izobraževanja v Črni gori skozi delo Vide Matjan. Influence of Slovenian culture and music pedagogy on the development of music education in Montenegro through work of Vida Matjan. 2019, 31, 16I-167.

\section{Martinović Bogojević, Jelena}

Sabina Vidulin in Jelena Martinović Bogojević: Poučevanje glasbe v reformiranem izobraževalnem sistemu: izkušnje iz Hrvaške in Črne gore. Music teaching in a reformed education system: Experience of Croatia and Montenegro. 2015, 23, 79-93.

Pogledi na osnovno glasbeno izobraževanje v Črni gori in Sloveniji. Views on the elementary music education in Montenegro and Slovenia. 2016, 25, $305-316$.

\section{Mastnak, Wolfgang}

Glasbena vzgoja in estetske terapije: integracija in aplikacija. I995, I, 28-38.

\section{Medňanská, Irena}

System der Grund-kunstschulen im Slowakischen Schulwesen. 2002, 4, 8594.

\section{Mihevc, Marija}

Sinergija umetnosti v luči gimnazijske glasbene didaktike. Synergy of various arts in relation to music education in secondary school. $2011,16,5-18$. 


\section{Milanković, Vera}

Milena Petrović, Gordana Ačić in Vera Milanković: Svobodne asociacije glasbenikov na dane glasbene koncepte. Musicians' free associations on the given music concepts. 2017, 26, 49-6I.

\section{Misson, Andrej}

O temeljih holistične analize. 1997, 2, 91-I09.

Oris poučevanja kontrapunkta in kratka predstavitev pouka na Akademiji za glasbo. 2000, 3, 78-88.

O problemih didaktike floridnega kontrapunkta. 2002, 4, 49-55.

Informatizacija poučevanja kontrapunkta na Akademiji za glasbo. 2005, 5 , II5-I28.

Orkestralna dela Vilka Ukmarja. Orchestral works of Vilko Ukmar. 2006, 6, IO3-II 4 .

Zborovska dela Vilka Ukmarja. Vilko Ukmar's choral works. 2006, 6, I03II 4 .

Mešani zbori Janka Ravnika. Janko Ravnik's works for mixed choir. 2007, 8, III-I2I.

Simfonična pesnitev Kurent Matije Bravničarja (1897-1977). Kurent: A symphonic poem by Matija Bravničar (1897-1977). 2008, 9, 87-102.

Pavel Šivic (1908-1995) - moški zbori. Pavel Šivic (1908-1995): Music for male voice choirs. 2009, II, III-I42.

Zbori Radovana Gobca za odrasle skupine. Compositions of Radovan Gobec for adult choirs. 2010, I3, 87-I3I.

Zborovska glasba Marijana Lipovška. Marijan Lipovšek's choral music. 20II, I5, II7-I 45.

Zbori Zvonimirja Cigliča (1921-2006). Choral works of Zvonimir Ciglič (I92I-2006). 2012, 17, 77-IOI.

Moški zbori Sama Vremšaka in njegovo delovanje pri kamniški Liri. Samo Vremšak's male-voice choirs and his role in Lira Kamnik. 20I4, 21, 83II9.

Poučevanje kontrapunkta in kompozicije na Slovenskem. The teaching of counterpoint and composition in the Slovenian territory. 2016, 25, 129I 47.

Razmislek o sodobnem slovenskem zborovstvu. Brief overview of contemporary choral music in Slovenia. 2018, 29, I35-I 44.

\section{Moličnik, Simona}

»Življenje ni praznik, je delavni dan.« Pavel Šivic, ob stoletnici rojstva. "Life is not a holiday but a working day." Birth centenary of Pavel Šivic. 2009, II, 7-I9.

\section{Mustajbašić, Vladimir}

Bojan Adamič u Beogradu. 2013, I8, 8I-108. 
Bojan Adamič v Beogradu. 2013, I8, I09-119.

\section{Nagode, Aleš}

Samospevi Matija Bravničarja. Matija Bravničar’s lieder. 2008, 9, 59-65.

Ustvarjalnost Pavla Šivica za glas in klavir. Pavel Šivic >s music for voice and piano. 2009, II, 83-92.

Samospevi Marijana Lipovška. Solo songs by Marijan Lipovšek. 20II, 15, 6976.

\section{Niermann, Franz}

Franz Niermann, Isolde Malmberg in Gerhard Sammer: Mrežno povezovanje za glasbeno izobraževanje v Evropi. Aktualna tematska težišča EAS. Netzwerk-arbeit für musikalische bildung in Europa. Aktuelle hemenschwerpunkte der EAS. 2006, 7, 42-68.

Franz Niermann, Sarah Hennessy, Adri de Vugt in Isolde Malmberg: Projekt meNet in učni izidi pri izobraževanju učiteljev glasbe. The meNet project and the learning outcomes in music teacher training. 2008, I0, 7-24.

\section{Novak, Katja}

Odnos mladih do klasične glasbe. Young people’s attitude to classical music concerts. $2018,28,6 \mathrm{I}-78$.

\section{Oblak, Breda}

Tradicija in sedanjost oddelka za glasbeno pedagogiko na Akademiji za glasbo. 1995, I, 8-10.

Izvor in pojmovanje strukture učnega načrta za splošni glasbeni pouk. I995, I, $17-26$.

Kje so korenine, ki zavirajo boljšo perspektivo glasbene vzgoje in kako je z glasbeno vzgojo dandanes. 1995, I, 49-60.

Ustvarjalnost v glasbeni vzgoji. 1997, 2, I2 I-I28.

Vpogled v značilne raziskave o ustvarjalnem učenju na področju glasbe. $2000,3,55-66$.

Osebnost Vilka Ukmarja v ogledalu glasbene pedagogike. The personality of Vilko Ukmar in the mirror of music pedagogy. 2006, 6, 9-2I.

Pavel Šivic - njegova naravnanost v poučevanju in temeljna zapuščina na področju slovenske glasbene pedagogike. Pavel Šivic: His orientation in teaching and essential legacy in the field of slovenian music pedagogy. 2009, II, 2I-53.

Narativni izraz poti skozi glasbeno šolstvo. Narrative expression of path through musical education. 2016, 25, 9-24.

\section{Oblak, Jerica}

Redefiniranje konsonance skozi spektralno manipulacijo oblikovanja zvoka, tonske uglasitve in kompozicijskega strukturiranja. Redefining 
consonance through spectral manipulation of sound design, tuning and compositional structuring. 2006, 7, 7-20.

\section{Pančur, Rudi}

Računalnik pri glasbenih dejavnostih. 1997, 2, I29-I4I.

\section{Parezanović, Kristina}

Percepcija kromatičnih intervalov in alteriranih akordov diatoničnega in kromatičnega tipa pri pouku solfeggia. Perception of chromatic intervals and altered chords of diatonic and chromatic type in teaching aural. 2009, I2, 97-108.

\section{Parker, Brian Frederick}

Spreminjajoča podoba glasbenega izobraževanja: $\mathrm{v}$ obdobje nove glasbene zavesti. The changing landscape of music education: Into an era of a new musical consciousness. 2006, 7, 69-82.

\section{Peklaj, Cirila}

Učitelj in učenci s posebnimi potrebami v glasbeni šoli. Teacher and students with special needs in the music school. 2010, I4, 53-64.

\section{Peschl, Wolf}

Kunst ist die Nabelschnur, die uns mit dem göttlichen verbindet zur Bedeutung der künstlerisch-kreativen Erziehung. 2002, 4, 72-84.

\section{Petrović, Milena}

Milena Petrović, Gordana Ačić in Vera Milanković: Svobodne asociacije glasbenikov na dane glasbene koncepte. Musicians' free associations on the given music concepts. 2017, 26, 49-6I.

Skupinsko petje in kolektivna identiteta. Group singing and collective identity. 2019, 30, 57-7I.

\section{Pompe, Gregor}

Poizkus slogovne določitve samospevov Vilka Ukmarja. Towards a stylistic determination of Vilko Ukmar's Lieder. 2006, 6, 57-67.

Violinske skladbe Matija Bravničarja in vprašanje »klasičnosti《v glasbi 20. stoletja. Matija Bravničar's violin compositions and the question of "the classical" in the $20^{\text {th }}$ century music. $2008,9,67-85$.

Operete Radovana Gobca. Operettas of Radovan Gobec. 2010, I3, I45-155. Pesmi iz mlina - med glasbeno imanenco in zvestobo literarni ideji. Pesmi iz mlina - between the immanence of music and fidelity to the literary idea. 2011 , I5, 77-88.

»Najbrž vedno pišem isto skladbo.«: ob klavirskem opusu Zvonimirja Cigliča. "I may always be writing the same piece.": On piano works of Zvonimir Ciglič. 2012, 17, 55-67. 
Zborovska ustvarjalnost Lojzeta Lebiča. Choral compositions of Lojze Lebič. 2018, 29, 73-89.

\section{Prezelj, Domen}

Bojan Adamič in njegova glasba za pihalni orkester. Bojan Adamič and his music for wind orchestra. 2013, 18, 63-72.

\section{Prša, Tihomir}

Jelena Blašković in Tihomir Prša: Izkušnje in odnos osnovnošolcev do gregorijanskega petja. Experience and attitude of primary school students towards Gregorian singing. 2017, 27, 133-144.

\section{Pucihar, Ilonka}

Improvizacija pri pouku klavirja v glasbeni šoli. Improvisation in music school piano instruction. 2014, 20, 5-23.

Ilonka Pucihar in Branka Rotar Pance: Telesni gib kot neločljivi del glasbenih dejavnosti. Bodily movement as inseparable part of musical activities. 2014, 20, 93-III.

Pomen vključevanja improvizacije v pouk klavirja. The importance of integrating improvisation in piano lessons. 2016, 25, 237-254.

\section{Pucihar, Jaka}

Adamičev prispevek k slovenski glasbi na področju big banda. Adamičs contribution to Slovenian big band music. 2013, I8, I2I-I32.

\section{Rakar, Bernarda}

Medpredmetno povezovanje pri pouku nauka o glasbi. Cross-curricular connections in the subject of music theory. 2014, 20, 25-49.

\section{Rauter, Brane}

Zgodovinski tok izdelovanja kitar na Slovenskem. Historical course of guitar making in the Slovenian territory. 2016, 24, II-28.

Zgodovinski vpogled $\mathrm{v}$ pouk kitare $\mathrm{v}$ slovenskem glasbenem šolstvu.

Historical insight into guitar lessons in Slovenian music education. 2016, 25, $103-127$.

\section{Razdevšek-Pučko, Cveta}

Didaktična zbirka za pouk glasbene vzgoje $\mathrm{v}$ osnovni šoli avtorice Brede Oblak spodbuja učitelje k poučevanju v skladu s sodobnimi psihološkimi spoznanji o učenju in poučevanju. 2002, 4, 7-I 4.

\section{Reichenberg, Mitja}

Bojan Adamič in filmska glasba. Bojan Adamič and film music. 2013, I8, 133I5O. 


\section{Reinstadler, Wolfgang}

Glasbena pedagogika in glasbenopedagoško raziskovanje na visokih šolah v Avstriji: institucije, raziskovalni pojmi in vidiki. 1995, I, 66-73.

Decentralizacija - deregulacija - avtonomija: kakšno v prihodnost orientirano glasbeno

pedagogiko ponujajo te dimenzije? 2000, 3, I08-II6.

\section{Ribizel, Tjaša}

Klavirska dela Marijana Lipovška. Piano compositions by Marijan Lipovšek. 20II, I5, 89-97.

Jernej Weiss, Tjaša Ribizel, Ines Kožuh in Matjaž Debevc: MySolfeggio: mobilna in tablična aplikacija za učenje solfeggia. MySolfeggio: Mobile and tablet application for learning of solfeggio. 2017, 27, 21-32.

\section{Rimkutè-Jankuvienè, Sandra}

Sandra Rimkutė-Jankuvienè in Rūta Girdzijauskienè: Kompetence učiteljev glasbe za spodbujanje glasbene ustvarjalnosti učencev s pomočjo MCT. Music teacher's competences to foster pupils' musical creativity through MCT. 2018, 28, 79-93.

\section{Rotar Pance, Branka}

Motivacija v procesu glasbenega izobraževanja. 1995, I, 39-48.

Struktura lika učitelja glasbe. 1997, 2, I43-150.

Raziskava motivacijske naravnanosti učiteljev za vzgojno-izobraževalno delo na področju glasbe. $2000,3,38-54$.

Vizualizacija v glasbenih slikanicah Brede Oblak. 2002, 4, 26-32.

Bibliografija Brede Oblak. 2002, 4, 99-108.

Barbara Sicherl-Kafol in Branka Rotar Pance: Tečaj accompagnato spremljava na poti vseživljenjskega učenja. 2005, 5, I29-I48.

Izobraževanje učiteljev glasbe v evropskih državah v projektu meNet. Music teacher training in European countries in the meNet project. 2008, Io, 25-39.

Šivičevi otroški in mladinski zbori v Grlici. Šivic >s music for children's and youth choirs published in Grlica. 2009, II, 93-110.

Delovanje Bojana Adamiča pri javni radijski oddaji Veseli tobogan. Bojan Adamičss role in radio show Veseli tobogan. 2013, 18, 189-202.

Ilonka Pucihar in Branka Rotar Pance: Telesni gib kot neločljivi del glasbenih dejavnosti. Bodily movement as inseparable part of musical activities. 2014, 20, 93-III.

Vremšakov opus za otroške in mladinske zbore. Vremšak's opus for child's and youth choirs. 20I4, 2I, 6I-8I.

Aktivno učenje glasbe in zasnova sodobne didaktike glasbe pri eksperimentalnem pouku Brede Oblak. Breda Oblak’s experimental 
music education: Active music learning and conception of modern music teaching. 2017, 27, 5-27.

\section{Rugelj, Jože}

Kristian Kolman in Jože Rugelj: Inovativni pristop k poučevanju violine na osnovi kognitivne teorije učenja $\mathrm{z}$ večpredstavnostjo. Innovative approach to teachning violin based on the cognitive theory of multimedia learning. 2019, 31, 83-99.

\section{Sajko, Nikolaj}

Lokovanja godalnega orkestra z vidika fizikalnih in fizioloških lastnosti produkcije in zaznavanja tona. Bowings in string orchestra from the viewpoint of physical and physiological characteristics of sound production and perception. 2010, 14, 5-27.

\section{Sammer, Gerhard}

Franz Niermann, Isolde Malmberg in Gerhard Sammer: Mrežno povezovanje za glasbeno izobraževanje v Evropi. Aktualna tematska težišča EAS. Netzwerk-arbeit für musikalische bildung in Europa. Aktuelle hemenschwerpunkte der EAS. 2006, 7, 42-68.

\section{Schaumberger, Helmut}

Ključne kompetence zborovodij za strokovno vodenje otroških in mladinskih pevskih zborov. How to sing professionally with children and adolescents: Core competencies of children's and couth choir directors. 2018, 29, 123-133.

\section{Senjan, Ivana}

Snježana Dobrota in Ivana Senjan: Vpliv modela recipročne povratne informacije glasbenega odziva na oblikovanje glasbenega okusa učencev. The impact of the reciprocal feedback model of musical response on shaping music taste of students. $2018,28,5-28$.

\section{Sicherl Kafol, Barbara}

Glasba in integrirani pouk. 1995, I, 74-90.

Opisno ocenjevanje pri glasbeni vzgoji na začetni stopnji osnovne šole. 1997, 2, $151-160$.

Vpliv celostne glasbene vzgoje na področja afektivno-socialnega, psihomotoričnega in kognitivnega razvoja. 2000, 3, 20-37.

Procesno načrtovanje didaktičnih gradiv za glasbeno vzgojo v začetnem obdobju osnovne sole. 2002, 4, 15-25.

Barbara Sicherl-Kafol in Branka Rotar Pance: Tečaj accompagnato spremljava na poti vseživljenjskega učenja. 2005, 5, I29-I 48.

Vseživljenjsko učenje v okviru projektnega dela meNet. Lifelong learning in the framework of project meNet. 2008, IO, 40-5I. 
Urban Kordeš, Barbara Sicherl-Kafol in Ada Holcar Brunauer: Model formativnega spremljanja znanja pri glasbeni vzgoji. A model of formative assessment in music education. 2013, 19, 5-22.

Sodobna razsežnost kurikulumov za glasbeno vzgojo Brede Oblak. Modern dimensions of Breda Oblak's music education curricula. 2017, 27, 4964 .

\section{Sivec, Jože}

Italijanske operne družbe na odru ljubljanskega gledališča v obdobju romantike. $1997,2,49-66$.

Aufstieg und Untergang der deutschen Oper im Ständischen Theater zu Ljubljana (Laibach) in den 3 oer und 4oer Jahren des i9. Jahrhunderts. 2005, 5, I 49-172.

\section{Smolej Fritz, Barbara}

Učenci s posebnimi potrebami v glasbeni šoli. Students with special needs in music school. 2010, I4, 65-70.

\section{Smolnikar, Ana}

Katarina Habe in Ana Smolnikar: Dejavniki oblikovanja glasbene samopodobe učencev, ki obiskujejo glasbeno šolo. Factors, that influence musical self-image in pupils, who attend music schools. $2016,25,255-$ 268 .

\section{Smrekar, Borut}

Terminus retuša v glasbeni strokovni literaturi in problem njegove rabe. 1997, 2, III-I2O.

Bravničarjev opus za glasbeno gledališče. Bravničar‘s music for stage. 2008, 9, IO3-I24.

Šivičev opus za glasbeno gledališče - (opera). Pavel Šivic's music for the stage: Opera. 2009, II, I55-166.

Operna dela Radovana Gobca. Operas of Radovan Gobec. 2010, 13, 133-1 43.

Marijan Lipovšek: kantata Orglar. Marijan Lipovšek’s cantata Oglar. 2011, I5, I $47-154$.

\section{Snoj, Jurij}

Notacijska podoba gregorijanskega korala v srednji Evropi. 2005, 5, 173-192.

\section{Stanič, Žiga}

Iskanje simetrij v proporcih vertikalnih harmonskih struktur. Search for symetries within proportions of harmonic vertical structures. 2006, 7, $2 I-4 I$. 
Hermenevtika glasbe: teoretski sistem ali pedagoška metoda? 2005, 5, 193228.

Marijan Lipovšek in poustvarjalnost. Marijan Lipovšek and performing art. 20II, I5, 55-67.

Leon Stefanija, Matej Bonin, Dimitrij Beuermann in Ada Holcar Brunauer: O koristi in škodi teorije glasbe v glasbenem izobraževanju na osnovnih in glasbenih šolah. Advantages and disadvantages of music theory in music education in primary and music school. 2016, 25, 203-216.

\section{Sulz, Josef}

Med ljudsko pesmijo, umetnostjo in rockom: glasbena pedagogika išče novo identiteto. 2000, 3, 89-107.

\section{Šantl Zupan, Karolina}

Pedagoško in umetniško delovanje učiteljev pihal. Pedagogical and artistic work of wind instrument teachers. 2016, 24, 57-71.

\section{Šarec, Veronika}

Vloga glasbe v taborskem gibanju na Slovenskem v letih od I868 do i87i. The role of music in the mass movement in Slovenia between year I868 and I871. 2010, I 4, 89-II5.

Marijan Lipovšek - direktor Slovenske filharmonije. Marijan Lipovšek, director of the Slovenian Philharmonic. 2011, I5, 39-53.

Orgelski opus Sama Vremšaka. The organ opus of Samo Vremšak. 201 4, 21, I2I-136.

\section{Šebesta, Josef}

Slovenski študentje na Konservatoriju v Pragi (1910-1917) in študentska leta Janka Ravnika. Slovene students at the Prague Conservatory (1910-1917) and Janko Ravnik's academics years. 2007, 8, 15-29.

\section{Šivic, Kaja}

Pavel Šivic - pianist: moji in njegovi spomini. Pavel Šivic: A pianist - My and his memories. 2009, II, 53-7I.

\section{Škojo, Tihana}

Tihana Škojo in Kristijan Žakić: Uporaba iger pri poučevanju glasbene umetnosti. The use of games in music education teaching. 20I8, 28, 5I59.

Tihana Škojo in Renata Jukić: Ocenjevanje pedagoških kompetenc učiteljev solfeggia. The assessment of pedagogical competences of solfeggio teachers. 2019, 3I, 69-8I. 
Orgle v cerkvi sv. Frančiška v Piranu. 1997, 2, 67-84.

Gallusovo obravnavanje mašnega ordinarija. 2005, 5, 229-248.

\section{Špendal, Manica}

Emerik Beran, Janáčkov učenec v Brnu. 1997, 2, 85-90.

\section{Štemberger, Tina}

Tina Štemberger in Majda Cencič: Pomen ustvarjalnosti vzgojiteljev s poudarkom na glasbeni ustvarjalnosti. The importance of preschool teachers' creativity with an emphasis on musical creativity. 2015, 23, 5-16.

Bogdana Borota in Tina Štemberger: Glasbene zmožnosti in potrebe po izobraževanju študentov Predšolske vzgoje. Musical abilities in relation to the needs to educate preschool education students. 2019, 31, 37-56.

\section{Uçan, Ali}

Glasbena in glasbenopedagoška srečanja med Vzhodom in Zahodom v Turčiji. 2000, 3, 117-126.

\section{Valant, Martina}

Opremljenost glasbenih šol z IKT ter njena uporaba pri pouku nauka o glasbi. How well are music schools equipped with ICT and how it is used to teach music. 2009, I2, 56-70.

Pouk v glasbeni šoli po šolski prenovi. Instruction in music schools after the school reform. 2016, 25, 217-236.

\section{Veršnik, Vojko}

Od raziskave do rabe glasbe: pesem kot komunikacija za dobrobit družbe. From research to use of music: A song as communication tool for the well-being of the society. 2019, 31, 117-132.

\section{Vidulin-Orbanić, Sabina}

Izvenšolske glasbene dejavnosti v osnovnošolskem sistemu. Extracurricular musical activities in the primary school system. 2009, I2, 4I-55.

\section{Vidulin, Sabina}

Razumevanje glasbe skozi inštrumentalno igro. Understanding music through playing instruments. 2013, 19, 23-39.

Sabina Vidulin in Jelena Martinović Bogojević: Poučevanje glasbe v reformiranem izobraževalnem sistemu: izkušnje iz Hrvaške in Črne gore. Music teaching in a reformed education system: Experience of Croatia and Montenegro. 2015, 23, 79-93.

Pristop »poslušanje in ustvarjanje glasbe « v funkciji boljšega razumevanja glasbe. The "listening to and making music" approach in the function of improving musical understanding. 2017, 27, 145-161. 
Strategije poslušanja glasbe in razumevanja glasbe v obvezni šoli. Strategies for listening to music and music appreciation in compulsory school. 2019, 31, 57-68.

\section{Vospernik, Hedvika}

Glasba v osnovni šoli. Že spet? 1995, I, II-16.

\section{Vrhunc, Larisa}

Odnos med besednim in glasbenim v mešanih zborih Jakoba Ježa. Interplay between textuality and music in mixed choirs of Jakob Jež. 2018, 29, 3560 .

\section{Weiss, Jernej}

Klavirski opus Vilka Ukmarja. Vilko Ukmar's piano composition. 2006, 6, $49-56$.

Janko Ravnik in njegov opus samospevov. Janko Ravnik and his lieder. 2007, $8,8 \mathrm{I}-90$.

Klavirski opus Pavla Šivica. Pavel Šivic’s piano output. 2009, II, 73-8I.

Tomčeva Stara pravda in Gobčev spor s političnimi oblastmi. Tomc's Stara pravda (Old Justice) and Gobec's quarrel with political authorities. 20ı。, I3, 75-86.

Samospevi Zvonimirja Cigliča. Art songs of Zvonimir Ciglič. 2012, 17, 6976.

Samospevi Sama Vremšaka. Solo songs by Samo Vremšak. 20I4, 2I, 5 I-59.

Jernej Weiss, Tjaša Ribizel, Ines Kožuh in Matjaž Debevc: MySolfeggio: mobilna in tablična aplikacija za učenje solfeggia. MySolfeggio: Mobile and tablet application for learning of solfeggio. 2017, 27, 21-32.

\section{Winkler Kuret, Lučka}

Vilko Ukmar - glasbeni kritik. Vilko Ukmar - Music critic. 2006, 6, 23-34.

Dela Janka Ravnika in glasbena kritika. Janko Ravnik's works and music criticism. 2007, 8, 57-66.

Matija Bravničar v luči glasbene kritike. Matija Bravničar in the light of music criticism. 2008, 9, 47-57.

Radovan Gobec - dirigent Akademskega pevskega zbora Tone Tomšič. Radovan Gobec - Choirmaster of the Academic Choir Tone Tomšič. 2010, $13,35-42$.

Lipovškovi pogledi na glasbo pred drugo vojno. Lipovšek's view of music before World War II. 2011, 15, 29-38

Razvoj učbenikov za nauk o glasbi: »Ni vse dobro, kar je novo, ni vse slabo, kar je staro.«

Development of textbooks for music theory class: "Not everything new is good, not everything old is bad." 2016, 25, 179-186. 


\section{Zadnik, Katarina}

Dejavniki glasbenega razvoja pri pet- do osemletnih učencih v glasbeni šoli. Factors of music development at five to eight year-old pupils in a music school. 2006, 7, 124-139.

Glasbeno mišljenje v nižjih razredih nauka o glasbi v glasbeni šoli. Musical thinking in lower classes of music theory at the music school. 2009, I2, 7I-96.

Razvoj ritmičnega in melodičnega posluha pri 8-letnih učencih v glasbeni šoli. Development of rhythmic and melodic pitch at 8-year-old pupils in a music school. 20II, 16, 19-4I.

Nauk o glasbi in njegova vloga v glasbenem šolstvu. Music theory and its role in music school education. 2013, 19, 4I-59.

Funkcionalna glasbena pismenost v nižjih razredih Nauka o glasbi. Functional musical literacy in the lower grades of Music Theory. 2015, 23, 49-7I.

Nauk o glasbi in solfeggio kot povezovalna člena v glasbeni šoli. Music theory and solfeggio as connective fields in music school education. 2016, 25, 187-201.

Katarina Zadnik in Danaja Koren: Montessori pedagogika in njena vloga pri nauku o glasbi v glasbeni šoli. Montessori pedagogy and its role in music theory in music school. 2017, 27, 175-190.

Bachovi cvetni plesi - alternativni pristop pri delu $\mathrm{z}$ učenci s posebnimi potrebami v glasbeni šoli. Bach flower dances - As an alternative working approach to pupils with special needs in music school. 2019, 31, IOI-IIS.

\section{Zager, Nataša}

Seznam del skladatelja Matije Bravničarja. List of works by the composer Matija Bravničar. 2008, 9, I25-162.

\section{Zalar, Konstanca}

Narativnost med otroki kot rezultat dela po ideji »Orff -Schulwerk«. Narrative theory in children as a result of the "Orff-Schulwerk approach". 2008, I0, 52-7I.

\section{Zimmerschied, Dieter}

Verweile doch, du bist so schön... Musik 1996 im Spannungsfeld von Funktions- und Wertewandel. 2002, 4, 65-7I.

\section{Zrilić, Smiljana}

Smiljana Zrilić in Tomislav Košta: Možnosti implementacije Hrvaškega nacionalnega izobraževalnega standarda v pouk glasbe za otroke $s$ posebnimi potrebami. The possibilities of implementing the Croatian 
national education standard in teaching music to pupils with special educational needs. 2008, 10, 72-84.

\section{Žakić, Kristijan}

Tihana Škojo in Kristijan Žakić: Uporaba iger pri poučevanju glasbene umetnosti. The use of games in music education teaching. 20I8, 28, 5I59.

\section{I.2 Povzetki magistrskih del (znanstveni študij) in doktorskih disertacij}

\section{Bačlija Susić, Blaženka}

Funkcionalna glasbena pedagogika pri učenju klavirja. Functional music pedagogy in piano learning. [Povzetek disertacije]. 2013, 19, 97-100.

\section{Bizjak, Marina}

Vokalna tehnika v adolescenci. [Povzetek disertacije]. 2017, 26, 79-80.

\section{Blašković, Jelena}

Pevsko izobraževanje študentov predšolske vzgoje na pedagoških fakultetah v Sloveniji in na Hrvaškem. [Povzetek disertacije]. 2015, 23, 95-98.

\section{Bohak, Tina}

Pevska šola Julija Betetta. Singing School of Julij Betetto. [Povzetek disertacije]. 2013, 19, 105.

\section{Borota, Bogdana}

Interakcija med pedagoškim in umetniškim delovanjem vzgojitelja. [Povzetek magistrskega dela]. 2005, 5, 249.

\section{Božič, Saša}

Zastopanost glasbenih zvrsti v nizozemskih, belgijskih in slovenskih splošnih srednjih šolah oziroma gimnazijah. [Povzetek magistrskega dela]. 2011, 16, I19-120.

\section{Breznik, Inge}

Razsežnosti ljudske glasbe v vzgajanju nacionalne identitete in razumevanju svetovnih kultur. [Povzetek disertacije]. 2006, 7, I40.

\section{Cerkovnik, Maja}

Primerjalna analiza uporabe desnega (senza sordino) pedala pri klavirskih delih W. A. Mozarta in L. v. Beethovna. [Povzetek magistrskega dela]. 2010, I4, 130. 


\section{Cigoj Krstulović, Nataša}

Glasbena vzgoja v konceptu nacionalne kulture od Glasbene matice do konservatorija (1872-1919) [Povzetek disertacije]. 2002, 4, 95-96.

\section{Dernjančević, Zdravko}

Tonski nizi v vokalni tradicionalni glasbi Slavonije. [Povzetek magistrskega dela]. 2011, 16, I29-130.

\section{Dernjančević, Zdravko}

Elementi ljudske glasbe Slavonije v delih skladateljev umetniške glasbe 20. stoletja. The elements of traditional Slavonian music in pieces of the $20^{\text {th }}$ century art music composers. [Povzetek disertacije/abstract of the doctoral thesis]. 2019, 30, 92-95.

\section{Flisar, Manja}

Razvoj srednje glasbene in baletne sole Maribor. [Povzetek magistrskega dela]. 2005, 5, 250.

\section{Goličnik, Tamara}

Izvajalna praksa klavirskih del Ludwiga van Beethovna. [Povzetek magistrskega dela]. 2011, 16, 133-135.

\section{Golobič, Špela}

Vpliv umetniških programov osrednjih slovenskih glasbenih institucij na kulturni razvoj in orientacijo šolske populacije. [Povzetek disertacije]. 2016, 24, 109-IIO.

\section{Habjanič Gaberšek, Manica}

Vloga in možnosti uporabe portfolia pri predmetu glasba v r. letniku gimnazije. [Povzetek magistrskega dela]. 2008, I0, I03-105.

\section{Horvat, Mirjana}

Oblikovanje profila učitelja glasbe v osnovnem šolstvu na Hrvaškem in v Sloveniji skozi zgodovinski razvoj do sodobnosti. The development of the formation of the profile of music teacher in primary schools in Croatia and Slovenia Through the historical development until the present time. [Povzetek disertacije]. 2013, 19, 95-96.

\section{Kavčič Pucihar, Ana}

Celostno poučevanje osnov igranja flavte za 7-letne učence. [Povzetek magistrskega dela]. 2011, 16, I27-I28.

\section{Kavčič Pucihar, Ana}

Učiteljeve strategije poučevanja pri individualnem inštrumentalnem pouku flavte $v$ glasbenih šolah. Teaching strategies in individual instrumental 
flute instruction in music schools. [Povzetek disertacije/abstract of the doctoral thesis]. 2019, 30, 97-101.

\section{Koban Dobnik, Mojca}

Gibalna dejavnost v glasbenem vzgojno-izobraževalnem procesu. [Povzetek magistrskega dela]. 2005, 5, 25 I.

\section{Košta, Tomislav}

Razvoj predmeta glasbena vzgoja v osnovni šoli na Hrvaškem od druge polovice 19. stoletja ter primerjalna analiza s Slovenijo in z Madžarsko. The development of the subject of music education in primary school in Croatia from the middle of the $19^{\text {th }}$ century until today and a comparative analysis with Slovenia and Hungary. [Povzetek disertacije]. 2013, I9, $\mathrm{IO}_{3-104}$

\section{Koter, Darja}

Instrumentarij salonov ter meščanskih in plemiških kapel v ptujski zbirki glasbil. [Povzetek magistrskega dela]. I995, I, I00-IOI.

\section{Koter, Darja}

Pojav in razvoj delavnic glasbil ob glasbenem šolstvu na Slovenskem.

[Povzetek disertacije]. 2000, 3, 127-132.

\section{Kralj Bervar, Sonja}

Ljubljanska delavska pevska društva od 2. polovice i9. stoletja do druge svetovne vojne. [Povzetek magistrskega dela]. 2005, 5, 252.

\section{Križnar, Franc}

Glasbeno-pedagoška literatura - sistematika. Sistem umetniških, pedagoških in znanstvenih informacij v glasbi; SUPZIG. [Povzetek disertacije]. 2000, 3, I33-I37.

\section{Krnić, Mario}

Interpretacija madrigalov Iacobusa Gallusa. [Povzetek magistrskega dela]. 2008, 10, 106.

\section{Kunej, Drago}

Optimalno predvajanje, restavriranje in uporaba prvih slovenskih etnomuzikoloških zvočnih zapisov. [Povzetek disertacije]. 2008, I0, 99IOI.

\section{Lokar Lavrenčič, Vlasta}

Razvojni akcijski projekt poučevanja tamburic na osnovni šoli. [Povzetek magistrskega dela]. 2011, I6, I2I-I22. 


\section{Mavrič, Primož}

Metode vadenja klavirske skladbe od prvega branja do nastopa. [Povzetek magistrskega dela]. 2011, 16, 131-132.

\section{Mihevc, Marija}

Likovne spodbude slovenskih likovnih umetnikov v glasbeno vzgojnoizobraževalnem procesu. [Povzetek disertacije]. 20II, I6, I37-I39.

\section{Može, Franc}

Učna gradiva za pouk glasbe $\mathrm{v}$ srednjih šolah. [Povzetek magistrskega dela]. 2006, 7, I $47-148$.

\section{Novak Jerman, Darinka}

Komparativna analiza učnih strategij in sposobnosti mladostnikov glede na glasbeno izobraževanje. [Povzetek disertacije]. 2016, 24, 107-108.

\section{Okorn, Franci}

Prenova glasbenega šolstva v Republiki Sloveniji v luči novih ciljev in nalog, mednarodnih listin ter vizije šolstva na stopnji osnovnega izobraževanja. [Povzetek magistrskega dela]. 1995, I, 98-99.

\section{Orešič, Urška}

Glasbeni stavek, formalna analiza in stilska opredelitev slovenske opere Ekvinokcij s pogledi na tuja glasbena dela, nastala iz podobnih vzpodbud. [Povzetek magistrskega dela]. 2011, 16, I23-125.

\section{Pesek-Pettan Albinca}

Otroci, starši in predšolska glasbena vzgoja in izobraževanje. [Povzetek disertacije]. I995, I, 9 I

\section{Pucihar, Ilonka}

Improvizacija - integralni del ustvarjalnega učenja in poučevanja klavirja. [Povzetek disertacije]. 2016, 24, 103-105.

\section{Rotar Pance, Branka}

Motivacija v procesu glasbenega izobraževanja. [Povzetek magistrskega dela]. 1995, I, 96-97.

\section{Sajko, Nikolaj}

Funkcionalnost in stilna ustreznost orkestralnih lokovanj. [Povzetek magistrskega dela]. 2010, 14, 127-129.

\section{Sam Palmić, Renata}

Tradicijska glasba in medkulturnost v osnovnošolski vzgoji in izobraževanju. Traditional music and interculturality in compulsory basic education. [Povzetek disertacije]. 2013, 19, IOI-IO2. 
Šantl Zupan, Karolina

Interakcija med umetniškim in pedagoškim izobraževanjem bodočih učiteljev pihalnih instrumentov. Interaction between artistic and pedagogical training for future teachers of wind instruments. [Povzetek disertacije/abstract of the doctoral thesis]. 2019, 30, 103-106.

\section{Šarec, Veronika}

Vzgojno-izobraževalna vloga Radia Ljubljana od ustanovitve leta 1928 do leta 1941. [Povzetek magistrskega dela]. 2006, 7, I 44.

\section{Šarec, Veronika}

Vloga zborovske glasbe v taborskem gibanju v I9. stoletju in njen vpliv na narodno identiteto Slovencev. [Povzetek disertacije]. 2010, I4, I32-134.

\section{Šipek-Vodnjov, Inge}

Vloga in položaj ljudske glasbe v tretjem triletju osnovne sole. [Povzetek magistrskega dela]. 2002, 4, 98 .

\section{Tomšič, Jasmina}

Povezovanje glasbe z ostalimi predmeti v zadnjem triletju osnovne šole. [Povzetek magistrskega dela]. 2006, 7, I 45-I 46.

\section{Valant, Martina}

Uporaba informacijsko komunikacijske tehnologije v glasbeni šoli. [Povzetek magistrskega dela]. 2009, I2, I09-IIO.

\section{Vargazon, Helena}

Olga Denac in Helena Vargazon: Vpliv institucionalne glasbene vzgoje na raven razvitosti melodičnega in ritmičnega posluha 5-6 let starih otrok. The effects of institutional music education on the level of melodic and rhytmic abilities development in 5-6 year olds. 2017, 27, 163-174.

\section{Vospernik, Hedvika}

Besedna komunikacija in uvajanje glasbene terminologije pri pouku glasbe na nižji stopnji osnovne šole. [Povzetek magistrskega dela]. 1995, I, $92-$ 93.

\section{Vrbančič - Osterc, Metka}

Uresničevanje poslušanja glasbe v tretjem triletju osnovne šole s stališča problematike učnega načrta. [Povzetek magistrskega dela]. 2006, 7, I49.

\section{Vrhnjak, Karin}

Akustično-zgodovinski oris flavte in pikola: pikolo v slovenskem glasbenem šolstvu. [Povzetek magistrskega dela]. 20IO, I4, I3I. 


\section{Winkler Kuret, Lučka}

Glasbeni učbeniki na Slovenskem od sredine 19. stoletja do sedemdesetih let 20. stoletja. [Povzetek magistrskega dela]. 2005, 5, 253.

\section{Zadnik, Katarina}

Opisno ocenjevanje na predšolski stopnji v glasbeni šoli. [Povzetek magistrskega dela]. 2005, 5, 254.

\section{Zadnik, Katarina}

Razvoj ritmičnega in melodičnega posluha pri 8-letnih učencih v glasbeni šoli. [Povzetek disertacije]. 20II, I6, I4I-I42.

\section{Zaveršnik, Majda}

Pojem solfeggia pri predmetu glasbeni stavek. [Povzetek magistrskega dela]. 1995, I, 94-95.

\section{Zupan, Alenka}

Vadenje pri učenju in poučevanju flavte. [Povzetek magistrskega dela]. 2008, IO, 102 .

\section{Žvar, Dragica}

Vzgojno-izobraževalni in splošni kulturni pomen slovenskih šolskih zborov. [Povzetek magistrskega dela]. 2002, 4, 97.

\section{Žvar, Dragica}

Razvoj in dosežki zborovske pesmi za otroke: otroška zborovska pesem 20. stoletja. [Povzetek disertacije]. 2006, 7, I 4I-I 43.

\subsection{Druga besedila}

Golob, Jani: Kako smo snemali portret Zvonimirja Cigliča. 2012, 17, 117II9.

Humer, Jože: Vilko Ukmar in Glasbena matica. 2006, 6, 127-130.

Koter, Darja: »Opera je še dovolj živa in nič ne kaže, da bi bila pripravljena umreti.« Monografija ob 8o-letnici Jožeta Sivca. Recenzija. Book Review. 20IO, I4, II7-I2I.

Oblak, Breda: Osebnost dr. Primoža Kureta. 2005, 5, 7-ı.

Repše, Vildana: Vprašanje izbire učnega gradiva za violino v nižjih razredih glasbene sole. The question of choice of learning material for violin in lower grades of music schools. 2017, 27, 207-210.

Rotar Pance, Branka: Teoretična izhodišča načrtovanja glasbene vzgoje v vrtcu avtorice Olge Denac. Recenzija. Book Review. 2010,14, I23-I25.

Svetina, Janez: O vlogi glasbe. 1995, I, 62-65. 
Suppan, Wofgang: Bojan Adamič - Seine Zeit, sein (Blas)musikalisches Umfeld. Bojan Adamič - njegov čas in takratno (godbeniško) glasbeno okolje. 2013, I8, 73-80.

Ukmar, Kristijan: Življenjska pot Vilka Ukmarja. Vilko Ukmar - Life History. 2006, 6, 3-8.

\section{KRONOLOŠKI SEZNAM OBJAVLJENIH ZVEZKOV}

Glasbeno-pedagoški zbornik Akademije za glasbo v Ljubljani. Urednik: Primož Kuret. 1995, I, IO2 strani - Primož Kuret: Za uvod. 5-7.

Glasbeno-pedagoški zbornik Akademije za glasbo v Ljubljani. Zbornik ob jubileju Primoža Kureta. Urednica: Breda Oblak. 1997, 2, 160 straniBreda Oblak: Uvodna beseda. 5.

Glasbeno-pedagoški zbornik Akademije za glasbo v Ljubljani. Urednik: Primož Kuret. Odgovorna urednica: Branka Rotar Pance. 2000, 3, 137 strani - Breda Oblak: Uvod. 5-6.

Glasbeno-pedagoški zbornik Akademije za glasbo v Ljubljani. Zbornik ob jubileju Brede Oblak. Urednik: Primož Kuret. Odgovorna urednica: Branka Rotar Pance. 2002, 4, Io8 strani - Primož Kuret: Uvod. 5-6.

Glasbeno-pedagoški zbornik Akademije za glasbo v Ljubljani. Zbornik ob 7o-letnici Primoža Kureta. Glavna urednica: Darja Koter. Tehnični urednik: Edo Škulj. 2005, 5, 256 strani - Pavel Mihelčič: Spomini na umetnost, posebej glasbeno. 5-6.

Glasbeno-pedagoški zbornik Akademije za glasbo v Ljubljani. Tematska publikacija Vilko Ukmar Igos-I9gI. Urednica: Darja Koter. 2006, 6, I78 strani - Primož Kuret: Uvodna beseda. I-2.

Glasbeno-pedagoški zbornik Akademije za glasbo v Ljubljani. Urednica: Branka Rotar Pance. 2006, 7, I 49 strani - Branka Rotar Pance: Predgovor. 5-6.

Glasbeno-pedagoški zbornik Akademije za glasbo v Ljubljani. Tematska publikacija Janko Ravnik I89I-Ig82. Urednica: Darja Koter. 2007, 8, I 45 strani - Darja Koter: Uvodne besede. 5-6.

Glasbeno-pedagoški zbornik Akademije za glasbo v Ljubljani. Tematska publikacija Matija Bravničar 1897-1977. Urednica: Darja Koter. 2008, 9, 163 strani - Pavel Mihelčič: Uvodne besede. 5-6.

Glasbeno-pedagoški zbornik Akademije za glasbo v Ljubljani. Urednica: Branka Rotar Pance. 2008, I0, 106 strani - Branka Rotar Pance: Predgovor. 5-6.

Glasbeno-pedagoški zbornik Akademije za glasbo v Ljubljani. Tematska publikacija Pavel Šivic (Igo8-1995). Urednica: Darja Koter. Asistent uredništva: Vinko Šorli. 2009, II, 190 strani - Pavel Mihelčič: Pavel Šivic, slovenski umetnik. 5-6. 
Glasbeno-pedagoški zbornik Akademije za glasbo v Ljubljani. Urednica: Branka Rotar Pance. 2009, I2, IIO strani.

Glasbeno-pedagoški zbornik Akademije za glasbo v Ljubljani. Tematska publikacija Radovan Gobec (Igog-I995). Urednica: Darja Koter. 2010, I3, I57 strani - Andrej Grafenauer: Uvodno razmišljanje. Introduction. 5.

Glasbeno-pedagoški zbornik Akademije za glasbo v Ljubljani. Urednica: Branka Rotar Pance. 2010, I4, 134 strani.

Glasbeno-pedagoški zbornik Akademije za glasbo v Ljubljani. Tematska publikacija Marijan Lipovšek (IgIo-Iggs). Urednica: Darja Koter. 20II, I5, 22I strani - Andrej Grafenauer: Uvodno razmišljanje. Introduction. 5 .

Glasbeno-pedagoški zbornik Akademije za glasbo v Ljubljani. Urednica: Branka Rotar Pance. 20II, I6, I 42 strani.

Glasbeno-pedagoški zbornik Akademije za glasbo v Ljubljani. Tematska publikacija Zvonimir Ciglič (Ig2I-2006). Urednica: Darja Koter. 20I2, I7, I23 strani - Andrej Grafenauer: Uvodno razmišljanje. Introduction. 5.

Glasbeno-pedagoški zbornik Akademije za glasbo v Ljubljani. Tematska publikacija Bojan Adamič (IgI2-Ig95). Urednica: Darja Koter. 2013, 17, 205 strani.

Glasbeno-pedagoški zbornik Akademije za glasbo v Ljubljani. Urednica: Branka Rotar Pance. 2013, 19, I05 strani.

Glasbenopedagoški zbornik Akademije za glasbo v Ljubljani. The Journal of Music Education of the Academy of Music in Ljubljana. Urednica: Branka Rotar Pance. 2014, 20, 127 strani.

Glasbenopedagoški zbornik Akademije za glasbo v Ljubljani. The Journal of Music Education of the Academy of Music in Ljubljana. Tematska publikacija/Thematic issue Samo Vremšak (1930-2004). Urednica: Darja Koter. Asistentka uredništva: Tina Bohak. 2014, 21, I67 strani.

Glasbenopedagoški zbornik Akademije za glasbo v Ljubljani. The Journal of Music Education of the Academy of Music in Ljubljana. Tematska publikacija/Thematic issue Primož Kuret. Ambasador slovenske kulture. Urednica: Darja Koter. Asistentka uredništva: Tina Bohak. Ponatis študij Primoža Kureta, objavljenih v nemškem jeziku v različnih tujih publikacijah v letih 1989-2013. 2015, 22, 311 strani - Darja Koter: Spremna beseda. 9-12. Geleitwort. 13-16.

Glasbenopedagoški zbornik Akademije za glasbo v Ljubljani. The Journal of Music Education of the Academy of Music in Ljubljana. Urednica: Branka Rotar Pance. 2015, 23, 98 strani.

Glasbenopedagoški zbornik Akademije za glasbo v Ljubljani. The Journal of Music Education of the Academy of Music in Ljubljana. Urednica: Branka Rotar Pance. Asistentka uredništva: Tina Bohak. 2016, 24, IIO strani - Branka Rotar Pance: Namesto uvoda. Instead of a Preface. 5-9. 
Glasbenopedagoški zbornik Akademije za glasbo v Ljubljani. The Journal of Music Education of the Academy of Music in Ljubljana. Tematska publikacija/Thematic issue Javno glasbeno solstvo na Slovenskem. Pogledi ob 200 letnici. Urednica: Branka Rotar Pance. Asistentka uredništva: Tina Bohak, 2016, 25, 354 strani - Primož Kuret: Uvodne misli ob 20o-letnici javnega glasbenega šolstva na Slovenskem. Preliminary Thoughts on $200^{\text {th }}$ Anniversary of Public Music Education in the Slovenian Territory. 5-8.

Glasbenopedagoški zbornik Akademije za glasbo v Ljubljani. The Journal of Music Education of the Academy of Music in Ljubljana. Urednica: Branka Rotar Pance. Asistentka uredništva: Tina Bohak. 2017, 26, 80 strani.

Glasbenopedagoški zbornik Akademije za glasbo v Ljubljani. The Journal of Music Education of the Academy of Music in Ljubljana. Tematska publikacija/Thematic issue Breda Oblak. Utemeljiteljica didaktike glasbe na Slovenskem. Urednica: Branka Rotar Pance. Asistentka uredništva: Tina Bohak, 2017, 27, 210 strani.

Glasbenopedagoški zbornik Akademije za glasbo v Ljubljani. The Journal of Music Education of the Academy of Music in Ljubljana. Urednica: Katarina Habe. 2018, 28, 93 strani.

Glasbenopedagoški zbornik Akademije za glasbo v Ljubljani. The Journal of Music Education of the Academy of Music in Ljubljana. Tematska publikacija/Thematic issue Jakob Jež (Ig28-). Tokovi sodobne zborovske glasbe. Urednica: Darja Koter. Asistentka uredništva: Tina Bohak, 20ı8, 29, I 44 strani.

Glasbenopedagoški zbornik Akademije za glasbo v Ljubljani. The Journal of Music Education of the Academy of Music in Ljubljana. Urednica: Katarina Habe. 2019, 30, 106 strani.

Glasbenopedagoški zbornik Akademije za glasbo v Ljubljani. The Journal of Music Education of the Academy of Music in Ljubljana. Tematska publikacija/Thematic issue Mostovi med formalnim in neformalnim glasbenim izobraževanjem. Urednica: Branka Rotar Pance. 2019, 31, I80 strani.

3. IMENSKO IN STVARNO VSEBINSKO KAZALO

3.I. Imensko vsebinsko kazalo

ADAMIČ, Bojan

Avsenak Pogačnik, Meri: Šanson Bojana Adamiča in Jugoslovanski šanson

- Rogaška. Bojan Adamičss chanson and festival Yugoslavian Chanson

- Rogaška. 2013, 18, 169-188. 
Frantar, Vladimir: Popevka in Bojan Adamič. Bojan Adamič and popular songs. 2013 , I8, I5I-168.

Koter, Darja: Bojan Adamič: The correlation between his creative and performing life. 2013, I8, 5-21.

Koter, Darja: Bojan Adamič: soodvisnost njegovega umetniškega in poustvarjalnega delovanja. 2013, I8, 23-35.

Križnar, Franc: Glasba Bojana Adamiča v času druge svetovne vojne. Bojan Adamič's music during World War II. 2013, I8, 37-6I.

Mustajbašić, Vladimir: Bojan Adamič u Beogradu. 2013, I8, 8I-I08.

Mustajbašić, Vladimir: Bojan Adamič v Beogradu. 2013, I8, I09-I19.

Prezelj, Domen: Bojan Adamič in njegova glasba za pihalni orkester. Bojan Adamič and his music for wind orchestra. 2013, 18, 63-72.

Pucihar, Jaka: Adamičev prispevek k slovenski glasbi na področju big banda. Adamič's contribution to slovenian big band music. 2013, I8, I2I-I32.

Reichenberg, Mitja: Bojan Adamič in filmska glasba. Bojan Adamič and film music. 2013, I8, 133-150.

Rotar Pance, Branka: Delovanje Bojana Adamiča pri javni radijski oddaji Veseli tobogan. Bojan Adamič's role in radio show Veseli tobogan. 2013, I8, 189-202.

Suppan, Wofgang: Bojan Adamič - Seine Zeit, sein (Blas)musikalisches Umfeld. Bojan Adamič - njegov čas in takratno (godbeniško) glasbeno okolje. $2013, \mathrm{I} 8,73-80$.

BERAN, Emerik

Špendal, Manica: Emerik Beran, Janáčkov učenec v Brnu. 1997, 2, 85-90.

\section{BETTETO, Julij}

Bohak, Tina: Nova spoznanja o življenju in delovanju pevca in pedagoga Julija Betetta (1885-1963). New facts about the life and work of opera singer and teacher Julij Betetto (1885-1963). 2013, 19, 75-94.

\section{BITENC SAMEC, Marija}

Bohak, Tina: »Hočem postati pevka« - Življenjska in ustvarjalna pot koncertne pevke, altistke Marije Bitenc Samec. "I want to become a singer" - The life and creative path of the concert singer, alto Marija Bitenc Samec. 2017, 26, 63-78.

\section{BRAVNIČAR, Matija}

Antoni, Luisa: Uredniško delo Matija Bravničarja. Matija Bravničar’s editorial work. 2008, 9, 33-45.

Koter, Darja: Matija (Frane) Bravničar - prispevek k biografiji. Towards a Bigraphy of Matija (Frane) Bravničar. 2008, 9, 7-24.

Kuret, Primož: Bravničarjeva »Srečanja in spomini«. Bravničar’s "Meetings and Reminiscences". 2008, 9, 25-32. 
Misson, Andrej: Simfonična pesnitev Kurent Matije Bravničarja (1897-1977). Kurent: A Symphonic Poem by Matija Bravničar (1897-1977). 2008, 9, 87-102.

Nagode, Aleš: Samospevi Matija Bravničarja. Matija Bravničar’s lieder. 2008, 9, 59-65.

Pompe, Gregor: Violinske skladbe Matija Bravničarja in vprašanje »klasičnosti« v glasbi 20. stoletja. Matija Bravničar’s violin compositions and the question of "the classical" in the $20^{\text {th }}$ Century Music. 2008, 9, 67-85.

Smrekar, Borut: Bravničarjev opus za glasbeno gledališče. Bravničar’s music for stage. 2008, 9, $103-124$.

Winkler Kuret, Lučka: Matija Bravničar v luči glasbene kritike. Matija Bravničar in the light of music criticism. 2008, 9, 47-57.

Zager, Nataša: Seznam del skladatelja Matije Bravničarja. List of works by the composer Matija Bravničar. 2008, 9, I25-I62.

\section{BRIŠNIK, Miloš}

Bohak, Tina: Miloš Brišnik - pozabljen mariborski pevski pedagog. Miloš Brišnik - The forgotten Maribor singing educator. 2016, 24, 29-43.

\section{CIGLIČ, Zvonimir}

Florjanc, Ivan: Orkestralna dela Zvonimirja Cigliča. Orchestral Works of Zvonimir Ciglič. 2012, 17, 31-54.

Golob, Jani: Kako smo snemali portret Zvonimirja Cigliča. 2012, I7, II7II9.

Koter, Darja: Zvonimir Ciglič: med recepcijo in avtorefleksijo. Zvonimir Ciglič: Between reception and self-reflection. 2012, 17, 103-116.

Križnar, Franc: Življenje in delo Zvonimirja Cigliča. Life and work of Zvonimir Ciglič. 2012, 17, 7-28.

Misson, Andrej: Zbori Zvonimirja Cigliča (1921-2006). Choral works of Zvonimir Ciglič (I92I-2006). 2012, 17, 77-IOI.

Pompe, Gregor: »Najbrž vedno pišem isto skladbo.«: ob klavirskem opusu Zvonimirja Cigliča. "I may always be writing the same piece.”: On piano works of Zvonimir Ciglič. 2012, 17, 55-67.

Weiss, Jernej: Samospevi Zvonimirja Cigliča. Art songs of Zvonimir Ciglič. $2012,17,69-76$.

\section{DRUZOVIČ, Hinko}

Koter, Darja: Hinko Druzovič - pedagog in čitalničar na Ptuju. 2002, 4, $39-48$.

\section{DUSÍK, František Josef Benedikt}

Barbo, Matjaž: Prispevek k orisu življenja in dela F. J. B. Dusíka. 2005, 5, 5368. 


\section{DVOŘÁK, Antonín}

Kuret, Primož: Die slowenish-tschechischen Musikbeziehungen und Antonín Dvořák. Slovensko-češki glasbeni stiki in Antonin Dvořák. Ponatis objave iz 1. 2007. 2015, 22, 184-190.

\section{EHRENFORTH, Karl Heinrich}

Brusniak, Friedhelm: Glasbena pedagogika/izobraževanje, quo vadis? Impulzi za razpravo o glasbeni pedagogiki/izobraževanju s perspektive Karla Heinricha Ehrenfortha. Music pedagogy/education, quo vadis? Impulses for a discussion about music pedagogy/education from the perspective of Karl Heinrich Ehrenforth. 2015, 23, 73-77.

\section{GALLUS, Iacobus}

Škulj, Edo: Gallusovo obravnavanje mašnega ordinarija. 2005. 5. 229-248.

\section{GOBEC, Radovan}

Gabrič, Aleš: Pevski zbori med tradicijo, revolucionarno normo in internacionalo. Choirs between the tradition, revolutionary standard and the internationale. 2010, $13,43-63$.

Gobec, Mitja: Radovan Gobec - moj profesor in vzornik. Radovan Gobec My professor and my idol. 2010, 13, 27-34.

Koter, Darja: Radovan Gobec - življenjska in ustvarjalna pot. Radovan Gobec's life and career. 2010, 13, 7-25.

Misson, Andrej: Zbori Radovana Gobca za odrasle skupine. Compositions of Radovan Gobec for adult choirs. 2010, 13, 87-131.

Pompe, Gregor: Operete Radovana Gobca. Operettas of Radovan Gobec. 2010, I3, I 45-I55.

Smrekar, Borut: Operna dela Radovana Gobca. Operas of Radovan Gobec. 2010, I3, I33-I 43.

Šarec, Veronika: Množična, revolucionarna in delavska pesem na Slovenskem, vpeta v nacionalno gibanje 19. stoletja in družbenopolitične direktive 20. Stoletja. Massive choirs, revolutionary and labour song in Slovenia, integrated with national movement of the isth century and sociopolitical directives of the 2oth century. $\quad 2010,1_{3}, 65-73$.

Weiss, Jernej: Tomčeva Stara pravda in Gobčev spor s političnimi oblastmi. Tomc's Stara pravda (Old Justice) and Gobec's quarrel with political authorities. 2010, 13, 75-86.

Winkler Kuret, Lučka: Radovan Gobec - dirigent Akademskega pevskega zbora Tone Tomšič. Radovan Gobec - Choirmaster of the Academic Choir Tone Tomšič. 2010, 13, 35-42.

\section{HAYDN, Joseph}

Kuret, Primož: Joseph Haydns Sakralwerke in Programmen der Philharmonischen Gesellschaft zu Ljubljana (Laibach). Haydnova 
sakralna dela na sporedih ljubljanske Filharmonične družbe. Ponatis objave iz 1. 2002. 2015, 22, 78-92.

\section{HERDER, Johann Gottfried}

Kuret, Primož: Johann Gottfried Herder und die Slowenen. Johann

Gottfried Herder in Slovenci. Ponatis objave iz 1. 2002. 2015, 22, 125-I32.

\section{IPAVEC, Benjamin}

Kuret, Primož: Ein Brief des slowenischen Komponisten Benjamin Ipavec an Leoš Janáček. Pismo slovenskega skladatelja Benjamina Ipavca Leošu Janáčku. Ponatis objave iz 1. 200I. 2015, 22, 19I-195.

\section{IPAVEC, Josip}

Kuret, Primož: Zemlinsky als Lehrer des slowenischen Komponisten Josip Ipavec. Zemlinsky - učitelj slovenskega skladatelja Josipa Ipavca. Ponatis objave iz l. 1995. 2015, 22, 204-208.

\section{JANÁČEK, Leoš}

Kuret, Primož: Ein Brief des slowenischen Komponisten Benjamin Ipavec an Leoš Janáček. Pismo slovenskega skladatelja Benjamina Ipavca Leošu Janáčku. Ponatis objave iz 1. 200I. 2015, 22, 191-195.

\section{JEŽ, Jakob}

Barbo, Matjaž: Sožitje vokala in instrumentala v kantatah Jakoba Ježa. Coexistence of vocal and instrumental paradigms in cantatas of Jakob Jež. 2018, 29, 6I-72.

Bohak Adam, Tina: »En, ten, tenera « - Ježevi otroški in mladinski zbori v Grlici. "En, ten, tenera" - Children's and youth choirs of Jakob Jež. 2018, 29, 17-33.

Koter, Darja: Jakob Jež - glasbeni samohodec. Jakob Jež - Musical maverick. 2018, 29, 5-16.

Vrhunc, Larisa: Odnos med besednim in glasbenim v mešanih zborih Jakoba Ježa. Interplay between textuality and music in mixed choirs of Jakob Jež. 20r8, 29, 35-60.

\section{KURET, Primož}

Bergant, Hubert: Hommage a Primož Kuret: mož, ki mu je uspela sinteza umetnostne zgodovine in muzikologije. 1997, 2, 9-22.

Koter, Darja: Bibliografija Primoža Kureta. 2005, 5, II-33.

Oblak, Breda: Osebnost dr. Primoža Kureta. 2005, 5, 7-ı.

Urednik: glasbena srečanja med vzhodom in zahodom. Praznični zbornik ob 6o-letnici Primoža Kureta. 1997, 2, 7-8. 


\section{LEBIČ, Lojze}

Pompe, Gregor: Zborovska ustvarjalnost Lojzeta Lebiča. Choral compositions of Lojze Lebič. 2018, 29, 73-89.

\section{LIPOVŠEK, Marijan}

Bagarič, Alenka: Seznam glasbenih del Marijana Lipovška. Bibliography of Marijan Lipovšek. 2011, I5, I8I-217.

Barbo, Matjaž: Iz komornega opusa Marijana Lipovška. From Marijan Lipovšek's Chamber Works. 2011, 15, 99-116.

Florjanc, Ivan: Orkestralna dela Marijana Lipovška - bibliografski popis in oris. Orchestral works by Marijan Lipovšek - Bibliographic list and outline. 2011, I5, I55-I79.

Koter, Darja: Portretna skica Marijana Lipovška - čas mladosti in zorenja. An outline of Marijan Lipovšek - His youth and maturing. 2011, I5, 7-28.

Misson, Andrej: Zborovska glasba Marijana Lipovška. Marijan Lipovšek's choral music. 20II, I5, II7-I45.

Nagode, Aleš: Samospevi Marijana Lipovška. Solo songs by Marijan Lipovšek. 2011, 15, 69-76.

Pompe, Gregor: Pesmi iz mlina - med glasbeno imanenco in zvestobo literarni ideji. Pesmi iz mlina - Between the immanence of music and fidelity to the literary idea. 20II, I5, 77-88.

Ribizel, Tjaša: Klavirska dela Marijana Lipovška. Piano compositions by Marijan Lipovšek. 2011, I5, 89-97.

Smrekar, Borut: Marijan Lipovšek: kantata Orglar. Marijan Lipovšek’s cantata Oglar. 2011, I5, I 47-I54.

Stefanija, Leon: Marijan Lipovšek in poustvarjalnost. Marijan Lipovšek and performing art. 2011, 15, 55-67.

Šarec, Veronika: Marijan Lipovšek - direktor Slovenske filharmonije. Marijan Lipovšek, Director of the Slovenian Philharmonic. 2011, I5, 3953.

Winkler Kuret, Lučka: Lipovškovi pogledi na glasbo pred drugo vojno. Lipovšek's view of music before World War II. 2011, I5, 29-38.

\section{MAHLER, Gustav}

Kuret, Primož: Mahler und Ljubljana/Laibach. Mahler v Ljubljani. Ponatis objave iz 1. 1989. 2015, 22, 162-169.

Kuret, Primož: Laibacher Orchesterverhältnisse und Mahler Orchesterbesetzung in Laibach. Ljubljanske orkestrske razmere in Mahlerjeva zasedba orkestra v Ljubljani. Ponatis objave iz 1. 1998. 2015, 22, $170-183$. 
Marković, Vedrana: Vpliv slovenske kulture in glasbene pedagogike na razvoj glasbenega izobraževanja v Črni gori skozi delo Vide Matjan. Influence of Slovenian culture and music pedagogy on the development of music education in Montenegro through work of Vida Matjan. 2019, 3I, I6I-I67.

\section{MERKÙ, Pavle}

Kuret, Stojan: Ljudsko izročilo Slovencev v Italiji v zborovskih delih Pavleta Merkùja. Folk tradition of Slovenians in Itay in the choral works of composer Pavle Merkù. 2018, 29, 91-I22.

\section{MOZART, Wofgang A madeus}

Kuret, Primož: Mozart-Rezeption in Slowenien. Recepcija Mozartovih del na Slovenskem. Ponatis objave iz 1. 1997. 2015, 22, 119-I24.

\section{NEEFE, Christian Gottlob}

Loos, Helmut: Das Monodram „Sophonisbe“ von Christian Gottlob Neefe. 2005, 5, 105-II 4 .

\section{OBLAK, Breda}

Bohak, Tina: Breda Oblak - spiritus agens seminarskega izobraževanja glasbenih pedagogov »Glasbeni Bovec «. Breda Oblak - Spiritus agens of the seminar education of music pedagogues, named "Glasbeni Bovec". $2017,27,65-75$.

Borota, Bogdana: Didaktične zbirke za glasbeno vzgojo Brede Oblak z diahrone perspective. Didactic sets by Breda Oblak from a diachronic perspective. 2017, 27, 29-48.

Razdevšek-Pučko, Cveta: Didaktična zbirka za pouk glasbene vzgoje v osnovni šoli avtorice Brede Oblak spodbuja učitelje k poučevanju v skladu s sodobnimi psihološkimi spoznanji o učenju in poučevanju. 2002, 4, 7-I 4.

Rotar Pance, Branka: Vizualizacija v glasbenih slikanicah Brede Oblak. 2002, 4, 26-32.

Rotar Pance, Branka: Bibliografija Brede Oblak. 2002, 4, 99-ı08.

Rotar Pance, Branka: Aktivno učenje glasbe in zasnova sodobne didaktike glasbe pri eksperimentalnem pouku Brede Oblak. Breda Oblak's experimental music education: Active music learning and conception of modern music teaching. 2017, 27, 5-27.

Sicherl Kafol, Barbara: Sodobna razsežnost kurikulumov za glasbeno vzgojo Brede Oblak. Modern dimensions of Breda Oblak's music education curricula. 2017, 27, 49-64. 


\section{OSTERC, Slavko}

Kuret, Primož: Slavko Osterc - Minutenopern. Slavko Osterc - minutne opere. Ponatis objave iz 1. 2005. 2015, 22, 274-278.

Kuret, Primož: Zwei verschiedene „Pater noster“von Slavko Osterc und Karol Pahor. Dva različna očenaša, Slavka Osterca in Karola Pahorja. Ponatis objave iz 1. 2007. 2015, 22, 279-283.

\section{PAHOR; Karol}

Kuret, Primož: Zwei verschiedene „Pater noster“ von Slavko Osterc und Karol Pahor. Dva različna očenaša, Slavka Osterca in Karola Pahorja. Ponatis objave iz 1. 2007. 2015, 22, 279-283.

\section{RAVNIK, Janko}

Bogunović Hočevar, Katarina: Fragment k zvrsti klavirske miniature njen »pravi« začetek v slovenski glasbeni literaturi? Exploring the piano miniature genre - its "real" beginnings in Slovene music? 2007, 8, 6779.

Dekleva, Igor: »Poslušaj pojoči zven klavirja.« Janko Ravnik - klavirski pedagog. "Listen to the singing sound of the piano." Janko Ravnik as piano teacher. $2007,8,45-56$.

Faganel, Tomaž: Med zbori ad aequales Janka Ravnika. Janko Ravnik's ad aequales choral works. 2007, 8, 9I-IIO.

Florjanc, Ivan: Skladbe sakralne narave Janka Ravnika. The sacred works of Janko Ravnik. 2007, 8, 123-145.

Koter, Darja: »Ljubljanska pianistična šola«. Janko Ravnik - utemeljitelj slovenske pianistične šole. “The Ljubljana piano-school”. Janko Ravnik the founder of the Slovene piano school. 2007, 8, 3I-43.

Kuret, Primož: Slovenska glasba po prvi svetovni vojni. Slovene music after WWI. 2007, 8, 7-I 4 .

Misson, Andrej: Mešani zbori Janka Ravnika. Janko Ravnik’s works for mixed choir. 2007,8 , III-I2I.

Šebesta, Josef: Slovenski študentje na Konservatoriju v Pragi (I910-1917) in študentska leta Janka Ravnika. Slovene students at the Prague Conservatory (I9I0-I917) and Janko Ravnik's academics years. 2007, 8, I5-29.

Weiss, Jernej: Janko Ravnik in njegov opus samospevov. Janko Ravnik and his lieder. 2007. 8. 8I-90.

Winkler Kuret, Lučka: Dela Janka Ravnika in glasbena kritika. Janko Ravnik's works and music criticism. 2007. 8. 57-66.

\section{SANTONINO, Paolo}

Kuret, Primož: Die Reisetagebücher des Paolo Santonino (I 485-I487). Popotni dnevnik Paola Santonina (1485-I 487). Ponatis objave iz l. 1999. 2015, 22, 17-24. 
SCHÖNBERG, Arnold

Andraschke, Peter: „Du sollst nicht, du mußt.“ Struktur und Textbehandlund in Schönbergs Chören op. 27 nr. I und 2. 2005, 5, 3752.

\section{ŠIVIC, Pavel}

Barbo, Matjaž: Pavel Šivic in Collegium musicum. Pavel Šivic and the Collegium Musicum. 2009, II, 37-52.

Bogunović Hočevar, Katarina: Pavel Šivic in operna kritika. Pavel Šivic and his operatic criticism. 2009, II, I 43-I52.

Florjanc, Ivan: Simfonija »Sentence $\ll-$ Šivičeva četrta simfonija? The "Sentences" Symphony: Šivic>s Fourth Symphony? 2009, II, I67-182.

Mihelčič, Pavel: Pavel Šivic, slovenski umetnik. 2009, II, 5-6.

Misson, Andrej: Pavel Šivic (1908 -1995) - moški zbori. Pavel Šivic (19081995): Music for male voice choirs. 2009, II, III-I 42.

Moličnik, Simona: »Življenje ni praznik, je delavni dan.« Pavel Šivic, ob stoletnici rojstva $\gg$ Life is not a holiday but a working day.« Birth centenary of Pavel Šivic. 2009, II, 7-I9.

Nagode, Aleš: Ustvarjalnost Pavla Šivica za glas in klavir. Pavel Šivic's music for voice and piano. 2009, II, 83-92.

Oblak, Breda: Pavel Šivic - njegova naravnanost v poučevanju in temeljna zapuščina na področju slovenske glasbene pedagogike. Pavel Šivic: His orientation in teaching and essential legacy in the field of Slovenian music pedagogy. 2009, II, 21-53.

Rotar Pance, Branka: Šivičevi otroški in mladinski zbori v Grlici. Šivic >s music for children's and youth choirs published in Grlica. 2009, II, 93IIO.

Smrekar; Borut: Šivičev opus za glasbeno gledališče - (opera). Pavel Šivic's Music for the Stage: Opera. 2009, II, I55-166.

Šivic, Kaja: Pavel Šivic - pianist. Moji in njegovi spomini. Pavel Šivic: A pianist - My and his memories. 2009, II, 53-7I.

Weiss, Jernej: Klavirski opus Pavla Šivica. Pavel Šivic’s piano output. 2009, II, 73-8I.

\section{UKMAR, Vilko}

Florjanc, Ivan: Komorna glasba Vilka Ukmarja. The chamber music of Vilko Ukmar. 2006, 6, 8I-IoI.

Humer, Jože: Vilko Ukmar in Glasbena matica. 2006, 6, I27-130.

Koter, Darja: Ljubljanska Opera pod vodstvom Vilka Ukmarja (1939-1945). The Ljubljana Opera under Vilko Ukmar. 2006, 6, 35-48.

Križnar, Franc: Estetika in stil Vilka Ukmarja. The aesthetics and style of Vilko Ukmar. 2006, 6, II5-I26.

Krstulović, Zoran: Seznam objavljenih del skladatelja Vilka Ukmarja. 2006, 6, I3I-175. 
Oblak, Breda: Osebnost Vilka Ukmarja v ogledalu glasbene pedagogike. The personality of Vilko Ukmar in the mirror of music pedagogy. 2006, 6, 9-2I.

Pompe, Gregor: Poizkus slogovne določitve samospevov Vilka Ukmarja. Towards a stylistic determination of Vilko Ukmar's lieder. 2006, 6, 5767.

Misson, Andrej: Orkestralna dela Vilka Ukmarja. Orchestral works of Vilko Ukmar. 2006, 6, I03-II 4.

Misson, Andrej: Zborovska dela Vilka Ukmarja. Vilko Ukmar's choral works. 2006, 6, I03-II4.

Ukmar, Kristijan: Življenjska pot Vilka Ukmarja. Vilko Ukmar - Life history. 2006, 6, 3-8.

Weiss, Jernej: Klavirski opus Vilka Ukmarja. Vilko Ukmar's piano composition. 2006, 6, 49-56.

Winkler Kuret, Lučka: Vilko Ukmar - glasbeni kritik. Vilko Ukmar Music critic. 2006, 6, 23-34.

\section{VREMŠAK, Samo}

Bohak, Tina: Solistična poustvarjalnost baritonista Sama Vremšaka. Solo career of baritone Samo Vremšak. 2014, 21, 33-49.

Florjanc, Ivan: Orkestralna dela Sama Vremšaka. Orchestral works by Samo Vremšak. 2014, 21, 137-166.

Koter, Darja: Samo Vremšak: Artist and pedagogue. 2014, 21, 5-20.

Koter, Darja: Umetnik in pedagog Samo Vremšak. 20I4, 2I, 2I-3I.

Misson, Andrej: Moški zbori Sama Vremšaka in njegovo delovanje pri kamniški Liri. Samo Vremšak's male-voice choirs and his role in Lira Kamnik. 2014, 21, 83-119.

Rotar Pance, Branka: Vremšakov opus za otroške in mladinske zbore. Vremšak's opus for child's and youth choirs. 20I4, 2I, 6I-8I.

Šarec, Veronika: Orgelski opus Sama Vremšaka. The organ opus of Samo Vremšak. 2014, 21, I21-I36.

Weiss, Jernej: Samospevi Sama Vremšaka. Solo songs by Samo Vremšak. 20I4, 2I, 5I-59.

\section{VREŽE, Jurče}

Koter, Darja: Vpliv Jurčeta Vrežeta na razvoj mladinskih pevskih zborov na Štajerskem. The influence of Jurče Vreže on the development of youth choirs in Styria. 2017, 27, 103-115.

\section{WAGNER, Richard}

Kuret, Primož: Wagner in den Konzert- und Opernprogrammen vor dem Ersten Weltkrieg in Ljubljana/Laibach. Wagner na ljubljanskih koncertnih in opernih sporedih pred prvo svetovno vojno. Ponatis objave iz 1. 2013. 2015, 22, 245-253. 


\section{WOLF, Hugo}

Kuret, Primož: „Alle Landschaft ist ein Seelenzustandt...“: Hugo Wolf seine Zeitgenossen und Nachfolger. »Vsa pokrajina je odraz duše ...«: Hugo Wolf - njegovi sodobniki in nasledniki. Ponatis objave iz 1. 200 . 2015, 22, 196-203.

\subsection{Stvarno vsebinsko kazalo}

\section{Bibliografija/Bibliography}

Bagarič, Alenka: Seznam glasbenih del Marijana Lipovška. Bibliography of Marijan Lipovšek. 2011, I5, I8I-217.

Koter, Darja: Bibliografija Primoža Kureta. 2005, 5, II-33.

Krstulović, Zoran: Seznam objavljenih del skladatelja Vilka Ukmarja. 2006, 6, I3I-I75.

Rotar Pance, Branka: Bibliografija Brede Oblak. 2002, 4, 99-ı08.

Zager, Nataša: Seznam del skladatelja Matije Bravničarja. List of works by the composer Matija Bravničar. 2008, 9, I25-I62.

Glasbena analiza/Music analysis

Misson, Andrej: O temeljih holistične analize. 1997, 2, 91-I09.

Glasbena ikonografija/Musical iconography

Koter, Darja: Čembalo na slovenskih in istrskih freskah. 1997, 2, 37-47

Glasbena pedagogika/Musical pedagogy

Bernhofer, Andreas: Herausforderungen und Entwicklungsfelder des österreichischen Musikschulwesens. Challenges and development potentials of the Austrian music school system. 2016, 25, 297-304.

Brusniak, Friedhelm: Glasbena pedagogika/izobraževanje, quo vadis? Impulzi za razpravo o glasbeni pedagogiki/izobraževanju s perspektive Karla Heinricha Ehrenfortha. Music Pedagogy/Education, quo vadis? Impulses for a discussion about music pedagogy/education from the perspective of Karl Heinrich Ehrenforth. 2015, 23, 73-77.

Cvetković Crvenica, Jelena, in Jovanović, Milica: Ocena akreditiranega profesionalnega programa usposabljanja na področju solfeggio v Srbiji 2011-2019. Evaluation of the accredited professional training program in the field of solfeggio in Serbia 2011-2019. 2019, 30, 31-55.

Čorić, Ana: Razvoj skupnostnih glasbenih dejavnostih v visokošolskem izobraževanju: delo na ozvočenih zgodbah. Developing community music activities in higher education system: Working on sounded stories. 2019, 31, 17-35.

Gortan-Carlin, Ivana Paula, in Lazarić, Lorena: Regionalna kulturna ozaveščenost študentov edukacijskih ved s posebnim poudarkom na regionalni glasbi Istre. Regional cultural awareness of educational 
sciences students with a special review of the Istrian regional music. 2017, 27, 117- I31.

Martinović Bogojević, Jelena: Pogledi na osnovno glasbeno izobraževanje v Črni gori in Sloveniji. Views on the elementary music education in Montenegro and Slovenia. 2016, 25, 305-316.

Niermann, Franz, Malmberg, Isolde, in Sammer, Gerhard: Mrežno povezovanje za glasbeno izobraževanje $\mathrm{v}$ Evropi. Aktualna tematska težišča EAS. Netzwerk-arbeit für musikalische bildung in Europa. Aktuelle hemenschwerpunkte der EAS. 2006, 7, 42-68.

Peschl, Wolf: Kunst ist die Nabelschnur, die uns mit dem göttlichen verbindet zur Bedeutung der künstlerisch-kreativen Erziehung. 2002, 4, $72-84$.

Petrović, Milena, Ačić, Gordana, in Milanković, Vera: Svobodne asociacije glasbenikov na dane glasbene koncepte. Musicians' free associations on the given music concepts. 2017, 26, 49-6I.

Petrović, Milena: Skupinsko petje in kolektivna identiteta. Group singing and collective identity. 2019, 30, 57-71.

Reinstadler, Wolfgang: Glasbena pedagogika in glasbenopedagoško raziskovanje na visokih šolah v Avstriji: institucije, raziskovalni pojmi in vidiki. 1995, I, 66-73.

Reinstadler, Wolfgang: Decentralizacija - deregulacija - avtonomija: kakšno v prihodnost orientirano glasbeno pedagogiko ponujajo te dimenzije? 2000, 3, 108-116.

Uçan, Ali: Glasbena in glasbenopedagoška srečanja med Vzhodom in Zahodom v Turčiji. 2000, 3, 117-126.

Vidulin, Sabina, in Martinović Bogojević, Jelena: Poučevanje glasbe v reformiranem izobraževalnem sistemu: izkušnje iz Hrvaške in Črne gore. Music teaching in a reformed education system: Experience of Croatia and Montenegro. 2015, 23, 79-93.

Glasbena pedagogika (Slovenija)/Musical pedagogy (Slovenia)

Kovačič, Mojca: Rastemo z opero: neformalno glasbeno izobraževanje mladostnikov in razvoj kompetenc. Growth through opera: Non-formal music education for youngsters and the development of competencies. 2019, 31, I33-I 44 .

Lokar Lavrenčič, Vlasta: Tamburica - od tradicionalnega inštrumenta do sodobne pedagoške prakse. Tamburitza - From a traditional instrument to modern pedagogical practice. 2011, 16, 43-56.

Oblak, Breda: Tradicija in sedanjost oddelka za glasbeno pedagogiko na Akademiji za glasbo. 1995, I, 8-10.

Oblak, Breda: Kje so korenine, ki zavirajo boljšo perspektivo glasbene vzgoje in kako je z glasbeno vzgojo dandanes. 1995, I, 49-60.

Oblak, Breda: Ustvarjalnost v glasbeni vzgoji. 1997, 2, I21-128. 
Rotar Pance, Branka: Motivacija v procesu glasbenega izobraževanja. 1995, I, 39-48.

Stefanija, Leon, Bonin, Matej, Beuermann, Dimitrij, in Holcar Brunauer, Ada: O koristi in škodi teorije glasbe v glasbenem izobraževanju na osnovnih in glasbenih šolah. Advantages and disadvantages of music theory in music education in primary and music school. 2016, 25, 203-216.

Veršnik, Vojko: Od raziskave do rabe glasbe: pesem kot komunikacija za dobrobit družbe. From research to use of music: A song as communication tool for the well-being of the society. 2019, 31, II7-I32.

Glasbena pedagogika, glasbeno šolstvo/Musical pedagogy, music schools

Antoni, Luisa: Raznolikost in bogastvo glasbenega šolanja na Primorskem. The diversity and wealth of musical education in Primorska region. 2016, 25, 287-296.

Bačlija Susić, Blaženka: Različni metodični pristopi pri pouku klavirja in storilnostna motivacija učencev. Various teaching methods in piano learning and student's achievement motivation. 2010, I4, 29-52.

Bernhofer, Andreas: Herausforderungen und Entwicklungsfelder des österreichischen Musikschulwesens. Challenges and development potentials of the Austrian music school system. 2016, 25, 297-304.

Beuermann, Dimitrij: Celostna glasbena šola. The holistic music school. 2016, 25, 317-338.

Habe, Katarina, in Smolnikar, Ana: Dejavniki oblikovanja glasbene samopodobe učencev, ki obiskujejo glasbeno šolo. Factors that influence musical self-image in pupils who attend music schools. 2016, 25, 255-268.

Habe, Katarina, in Kržič, Vida: Doživljanje izvajalske anksioznosti učencev glasbene šole v zgodnjem mladostništvu. Experiencing performance anxiety in music school pupils in early adolescence. 2017 , 26, 33-46.

Ivec, Anja: Pomen motivacije v projektu $\gg$ Dijaki komponisti« Konservatorija Maribor. The meaning of motivation in the student composer project at Conservatory Maribor. 2017, 27, 191-199.

Kavčič Pucihar, Ana: Učiteljeve strategije poučevanja pri individualnem inštrumentalnem pouku flavte v glasbenih šolah. Teaching strategies in individual instrumental flute instruction in music schools. 2019, 30, 5-29.

Kolman, Kristian, in Rugelj, Jože: Inovativni pristop k poučevanju violine na osnovi kognitivne teorije učenja z večpredstavnostjo. Innovative approach to teachning violin based on the cognitive theory of multimedia learning. 2019, 31, 83-99.

Križnar, Franc: Didaktična in metodična glasbena literatura v piramidi slovenskega glasbenega šolstva v izdajah Založbe Zavoda RS za šolstvo. 
Didactic and methodic music literature in pyramid of Slovenian music education published by the National Education Institute. 2016, 25, 339349 .

Marković, Vedrana: Vloga in pomen urjenja posluha (solfeggio) ter aktivnih učnih procesov v začetnem obdobju glasbenega izobraževanja. Role and significance of ear training (solfeggio) and active learning processes in the innitial phase of music education. 2008, 10, 85-98.

Martinović Bogojević, Jelena: Pogledi na osnovno glasbeno izobraževanje $\mathrm{v}$ Crni gori in Sloveniji. Views on the elementary music education in Montenegro and Slovenia. 2016, 25, 305-316.

Med ňanská, Irena: System der Grund-kunstschulen im Slowakischen Schulwesen. 2002, 4, 85-94.

Pucihar, Ilonka: Improvizacija pri pouku klavirja v glasbeni šoli. Improvisation in music school piano instruction. 201 4, 20, 5-23.

Pucihar, Ilonka: Pomen vključevanja improvizacije v pouk klavirja. The importance of integrating improvisation in piano lessons. 2016, 25, 237254 .

Pucihar, Ilonka in Rotar Pance, Branka: Telesni gib kot neločljivi del glasbenih dejavnosti. Bodily movement as inseparable part of musical activities. 2014, 20, 93-III.

Rakar, Bernarda: Medpredmetno povezovanje pri pouku nauka o glasbi. Cross-curricular connections in the subject of music theory. 20I4, 20 , 25-49.

Valant, Martina: Pouk v glasbeni šoli po šolski prenovi. Instruction in music schools after the school reform. 2016, 25, 217-236.

Winkler Kuret, Lučka: Razvoj učbenikov za nauk o glasbi: »Ni vse dobro, kar je novo, ni vse slabo, kar je staro.« Development of textbooks for music theory class: "Not everything new is good, not everything old is bad." 2016, 25, 179-186.

Weiss, Jernej, Ribizel, Tjaša, Kožuh, Ines, in Debevc, Matjaž: MySolfeggio: mobilna in tablična aplikacija za učenje solfeggia. MySolfeggio: Mobile and tablet application for learning of solfeggio. 2017, 27, 21-32.

Zadnik, Katarina: Dejavniki glasbenega razvoja pri pet- do osemletnih učencih v glasbeni šoli. Factors of music development at five to eight year-old pupils in a music school. 2006, 7, 124-139.

Zadnik, Katarina: Glasbeno mišljenje v nižjih razredih nauka o glasbi v glasbeni šoli. Musical thinking in lower classes of music theory at the music school. 2009, 12, 71-96.

Zadnik, Katarina: Razvoj ritmičnega in melodičnega posluha pri 8-letnih učencih v glasbeni šoli. Development of rhythmic and melodic pitch at 8-year-old pupils in a music school. 2011, 16, 19-4I. 
Zadnik, Katarina: Nauk o glasbi in njegova vloga v glasbenem šolstvu. Music theory and its role in music school education. 2013, 19, 4I-59.

Zadnik, Katarina: Funkcionalna glasbena pismenost v nižjih razredih Nauka o glasbi. Functional musical literacy in the lower grades of Music Theory. 2015, 23, 49-7I.

Zadnik, Katarina: Nauk o glasbi in solfeggio kot povezovalna člena v glasbeni šoli. Music Theory and Solfeggio as Connective Fields in Music School Education. 2016, 25, 187-201.

Zadnik, Katarina, in Koren, Danaja: Montessori pedagogika in njena vloga pri nauku o glasbi v glasbeni šoli. Montessori pedagogy and its role in music theory in music school. 2017, 27, 175-190.

Zadnik, Katarina: Bachovi cvetni plesi - alternativni pristop pri delu z učenci s posebnimi potrebami v glasbeni šoli. Bach flower dances - As an alternative working approach to pupils with special needs in music school. 20I9, 3I, IOI-II5.

Glasbena pedagogika, IKT/Musical pedagogy, ICT

Borota, Bogdana: Računalniško okolje ter glasbeni čas v igri in slikovnem zapisu. Computer environment and musical time in play and image format. 2006, 7, 83-104.

Kolman, Kristian in Rugelj, Jože: Inovativni pristop k poučevanju violine na osnovi kognitivne teorije učenja $\mathrm{z}$ večpredstavnostjo. Innovative approach to teachning violin based on the cognitive theory of multimedia learning. 2019, 31, 83-99.

Pančur, Rudi: Računalnik pri glasbenih dejavnostih. 1997, 2, I29-I4I.

Valant, Martina: Opremljenost glasbenih šol z IKT ter njena uporaba pri pouku nauka o glasbi. How well are music schools equipped with ICT and how it is used to teach music. 2009, 12, 56-70.

Weiss, Jernej, Ribizel, Tjaša, Kožuh, Ines, in Debevc, Matjaž: MySolfeggio: mobilna in tablična aplikacija za učenje solfeggia. MySolfeggio: Mobile and tablet application for learning of solfeggio. 2017, 27, 2I-32.

Glasbena pedagogika in glasbena teorija/Musical pedagogy and music theory

Florjanc, Ivan: Harmonija - traktati in učbeniki v slovenščini. Premislek ob 200-letnici javnega glasbenega šolstva v Sloveniji. Harmony - Treatises and textbooks in Slovenian. reflection upon the $200^{\text {th }}$ anniversary of public music education in Slovenia. 2016, 25, I 49-178.

Kiš Žuvela, Sanja: Ko se nepremični (fiksni) »DO« začne premikati: večpomenskost intonančnih zlogov. When fixed “DO” tends to move: The ambiguity of the solfège syllabary. 2018, 28, 29-49.

Križnar, Franc: Zgodovinski pogled na interval kvarto in kvinto s posamičnimi poudarki v slovenski glasbi 20. stoletja. 2002, 4, 56-64. 
Misson, Andrej: Oris poučevanja kontrapunkta in kratka predstavitev pouka na Akademiji za glasbo. 2000, 3, 78-88.

Misson, Andrej: O problemih didaktike floridnega kontrapunkta. 2002, 4, 49-55.

Misson, Andrej: Informatizacija poučevanja kontrapunkta na Akademiji za glasbo. 2005, 5, II5-I28.

Misson, Andrej: Poučevanje kontrapunkta in kompozicije na Slovenskem. The teaching of counterpoint and composition in the Slovenian territory. 2016, 25, 129-I 47 .

Oblak, Jerica: Redefiniranje konsonance skozi spektralno manipulacijo oblikovanja zvoka, tonske uglasitve in kompozicijskega strukturiranja. Redefining consonance through spectral manipulation of sound design, tuning and compositional structuring. 2006, 7, 7-20.

Parezanović, Kristina: Percepcija kromatičnih intervalov in alteriranih akordov diatoničnega in kromatičnega tipa pri pouku solfeggia. Perception of chromatic intervals and altered chords of diatonic and chromatic type in teaching aural. 2009, I2, 97-108.

Smrekar, Borut: Terminus retuša v glasbeni strokovni literaturi in problem njegove rabe. 1997, 2, III-I2O.

Stanič, Žiga: Iskanje simetrij v proporcih vertikalnih harmonskih struktur. Search for symetries within proportions of harmonic vertical structures. 2006, 7, 2I-4I.

Glasbena pedagogika in hermenevtika/Musical pedagogy and hermeneutic

Stefanija, Leon: Hermenevtika glasbe : teoretski sistem ali pedagoška metoda? 2005, 5, 193-228.

Glasbena pedagogika, ocenjevanje/Musical pedagogy, assessment

Borota, Bogdana: Dokumentacija v vlogi spremljanja glasbenega razvoja otroka. Documentation as a part of the assessment of music development. 2009, 12, 5-19.

Kordeš, Urban, Sicherl-Kafol, Barbara, in Holcar Brunauer, Ada:

Model formativnega spremljanja znanja pri glasbeni vzgoji. A model of formative assessment in music education. 2013, 19, 5-22.

Sicherl-Kafol, Barbara: Opisno ocenjevanje pri glasbeni vzgoji na začetni stopnji osnovne šole. 1997, 2, 151-160.

Glasbena pedagogika, predšolska vzgoja/Musical pedagogy, early childhood education

Blašković, Jelena: Glasbeni profil študentov predšolske vzgoje glede na njihovo predhodno izobraževanje. Understanding the early childhood education students' musical profile with regard to their educational background. 2014, 20, 51-70. 
Blašković, Jelena: Učinki pevskega izobraževanja na nekatere glasbene dosežke študentov predšolske vzgoje. The effect of singing education on some preschool education students' music achievements. 2015, 23, 17-37.

Borota, Bogdana: Dokumentacija v vlogi spremljanja glasbenega razvoja otroka. Documentation as a part of the assessment of music development. 2009, 12, 5-19.

Borota, Bogdana, in Štemberger, Tina: Glasbene zmožnosti in potrebe po izobraževanju študentov Predšolske vzgoje. Musical abilities in relation to the needs to educate preschool education students. 2019, 31, 37-56.

Denac, Olga: Glasbena vzgoja in celostni razvoj otrokove osebnosti. 2000, 3, 7-19.

Denac, Olga: Kurikulum za vrtce in načrtovanje glasbene vzgoje. 2005, 5 , 83-94.

Denac, Olga: Uresničevanje kurikuluma za vrtce v procesu operativnega načrtovanja glasbene vzgoje. Realizing of the curriculum for kindergartens in the process of operative planning of music education. 2006, 7, 105-I23.

Denac, Olga, in Vargazon, Helena: Vpliv institucionalne glasbene vzgoje na raven razvitosti melodičnega in ritmičnega posluha 5-6 let starih otrok. The effects of institutional music education on the level of melodic and rhytmic abilities development in 5-6 year olds. 2017, 27, I63-I74.

Štemberger, Tina, in Cencič, Majda: Pomen ustvarjalnosti vzgojiteljev s poudarkom na glasbeni ustvarjalnosti. The importance of preschool teachers' creativity with an emphasis on musical creativity. 2015, 23, 5-16.

Glasbena pedagogika, splošno šolstvo/Musical pedagogy, general education

Ajtnik, Milka: Uveljavljene aplikacije poslušanja glasbe v splošnem izobraževanju. 2000, 3, 67-77.

Blašković, Jelena, in Prša, Tihomir: Izkušnje in odnos osnovnošolcev do gregorijanskega petja. Experience and attitude of primary school students towards gregorian singing. 2017, 27, 133-144.

Dobrota, Snježana, in Barbarić, Sara: Stališča hrvaških osnovnošolcev do glasbenega pouka. Croatian elementary school students' attitudes towards music lessons. 2017, 26, 5-19.

Dobrota, Snježana in Senjan, Ivana: Vpliv modela recipročne povratne informacije glasbenega odziva na oblikovanje glasbenega okusa učencev. The impact of the reciprocal feedback model of musical response on shaping music taste of students. $2018,28,5-28$.

Girdzijauskienė, Rūta: Kreativno izražanje osnovnošolskih otrok pri petju. Primary school children's creative expression in singing. 2016, 24, 45-55. 
Lešnik, Ivan: Kakovost pevske dejavnosti v prvem triletju osnovne sole. Singing quality in the first triennium of primary school. 2009, I2, 2040.

Mihevc, Marija: Sinergija umetnosti v luči gimnazijske glasbene didaktike. Synergy of various arts in relation to music education in secondary school. 20II, 16, 5-18.

Oblak, Breda: Izvor in pojmovanje strukture učnega načrta za splošni glasbeni pouk. 1995, I, 17-26.

Oblak, Breda: Vpogled v značilne raziskave o ustvarjalnem učenju na področju glasbe. 2000, 3, 55-66.

Rotar Pance, Branka: Vizualizacija v glasbenih slikanicah Brede Oblak. 2002, 4, 26-32.

Sicherl-Kafol, Barbara: Glasba in integrirani pouk. 1995, I, 74-90.

Sicherl-Kafol, Barbara: Vpliv celostne glasbene vzgoje na področja afektivno-socialnega, psihomotoričnega in kognitivnega razvoja. 2000, 3, 20-37.

Sicherl-Kafol, Barbara: Procesno načrtovanje didaktičnih gradiv za glasbeno vzgojo v začetnem obdobju osnovne šole. 2002, 4, 15-25.

Škojo, Tihana, in Žakić, Kristijan: Uporaba iger pri poučevanju glasbene umetnosti. The use of games in music education teaching. 20I8, 28, 5I59.

Vidulin-Orbanić, Sabina: Izvenšolske glasbene dejavnosti v osnovnošolskem sistemu. Extracurricular musical activities in the primary school system. 2009, I2, 4I-55.

Vidulin, Sabina: Razumevanje glasbe skozi inštrumentalno igro. Understanding music through playing instruments. 2013, 19, 23-39.

Vidulin, Sabina: Strategije poslušanja glasbe in razumevanja glasbe v obvezni šoli. Strategies for listening to music and music appreciation in compulsory school. 2019, 31, 57-68.

Vospernik, Hedvika: Glasba v osnovni šoli. Že spet? 1995, I, II-I6.

Zalar, Konstanca: Narativnost med otroki kot rezultat dela po ideji $\gg$ Orff -Schulwerk «. Narrative theory in children as a result of the "OrffSchulwerk approach". 2008, 10, 52-7I.

Glasbena pedagogika, vokalna tehnika/Musical pedagogy, vocal technique

Blašković, Jelena: Učinki pevskega izobraževanja na nekatere glasbene dosežke študentov predšolske vzgoje. The effect of singing education on some preschool education students' music achievements. 2015, 23, 17-37.

Bizjak, Marina, in Freer, Patrick: Ali se zavedamo pomena vokalne tehnike $\mathrm{v}$ adolescenci? Do we realize the importance of vocal technique in adolescence? 2015, 23, 39-48. 
Bizjak, Marina: Pedagoški pristopi pri poučevanju petja v času glasovnih sprememb. Pedagogical approaches for teaching singing at the time of voice change. $2017,27,201-206$.

Schaumberger, Helmut: Ključne kompetence zborovodij za strokovno vodenje otroških in mladinskih pevskih zborov. How to sing professionally with children and adolescents. core competencies of children's and couth choir directors. 2018, 29, I23-133.

\section{Glasbena umetnost, naracija/Music, narration}

Marčun, Andreja: Pomen glasbene umetnosti v povezavi z naracijo. The importance of music in conjunction with narration. 2016, 24, 73-86.

Oblak, Breda: Narativni izraz poti skozi glasbeno šolstvo. Narrative expression of path through musical education. 2016, 25, 9-24.

Glasbena vzgoja in estetika glasbe/Music education and aesthetics of music

Denac, Olga: Estetska vzgoja in načrtovanje učnega procesa glasbene vzgoje. $2002,4,33-38$.

Crowther, Paul: Glasba kot virtualna izraznost. Music as virtual expression. 2017, 27, 95-102.

Sulz, Josef: Med ljudsko pesmijo, umetnostjo in rockom. Glasbena pedagogika išče novo identiteto. 2000, 3, 89-107.

Zimmerschied, Dieter: Verweile doch, du bist so schön... Musik 1996 im Spannungsfeld von Funktions- und Wertewandel. 2002, 4, 65-7I.

Glasbena vzgoja in filozofija/Music education and philosophy

Parker, Brian Frederick: Spreminjajoča podoba glasbenega izobraževanja: v obdobje nove glasbene zavesti. The changing landscape of music education: Into an era of a new musical consciousness. 2006, 7, 69-82.

Svetina, Janez: O vlogi glasbe. 1995, I, 62-65.

Glasbena vzgoja in muzikoterapija/Music education and musicotherapy

Mastnak, Wolfgang: Glasbena vzgoja in estetske terapije. integracija in aplikacija. 1995, I, 28-38.

Glasbena vzgoja, učenci sposebnimi potrebami/Music education, pupils with special needs

Lapuh, Alja: Usvajanje glasbenega znanja in veščin pri otrocih z Aspergerjevim sindromom. Adoption of musical knowledge and skills in children with Asperger's syndrome. 2019, 30, 73-91.

Marčun, Andreja: Poučevanje učencev s posebnimi potrebami v glasbenih šolah - nekatere metode in oblike pedagoškega dela. Teaching children with special needs in music school - Some methods and forms of pedagogical work. 2016, 25, 269-286.

Peklaj, Cirila: Učitelj in učenci s posebnimi potrebami v glasbeni šoli. Teacher and students with special needs in the music school. 2010, I4, $53-64$. 
Zrilić, Smiljana in Košta, Tomislav: Možnosti implementacije Hrvaškega nacionalnega izobraževalnega standarda $\mathrm{v}$ pouk glasbe za otroke $s$ posebnimi potrebami. The possibilities of implementing the Croatian national education standard in teaching music to pupils with special educational needs. 2008, 10, 72-84.

\section{Glasbila/Instruments}

Biffio, Gesa: Nove razširitve lepega tona na violončelu. New extensions of the beautiful cello tone. 2011, 16, 77-107.

Haas, Miha: Tonske barve na klavirju: akustična predispozicija ali kontekstualna iluzija? Piano timbre: Acoustic predisposition or contextual illusion? 2016, 24, 87-102.

Pucihar, Ilonka: Pomen vključevanja improvizacije v pouk klavirja. The importance of integrating improvisation in piano lessons. 2016, 25, 237254 .

Rauter, Branislav: Zgodovinski vpogled v pouk kitare v slovenskem glasbenem šolstvu. Historical insight into guitar lessons in Slovenian music education. 2016, 25, 103-127.

Repše, Vildana: Vprašanje izbire učnega gradiva za violino v nižjih razredih glasbene sole. The question of choice of learning material for violin in lower grades of music schools. 2017, 27, 207-210.

Sajko, Nikolaj: Lokovanja godalnega orkestra z vidika fizikalnih in fizioloških lastnosti produkcije in zaznavanja tona. Bowings in string orchestra from the viewpoint of physical and physiological characteristics of sound production and perception. 2010, 14, 5-27.

Škulj, Edo: Orgle v cerkvi sv. Frančǐška v Piranu. 1997, 2, 67-84.

\section{Kompozicija/Composition}

Andraschke, Peter: „Du sollst nicht, du mußt.“ Struktur und

Textbehandlund in Schönbergs Chören op. 27 nr. I und 2. 2005, 5, 3752.

Dernjančević, Zdravko: Slavonski folklorni napevi z vidika tonskih nizov. Slavonian folk tunes from the aspect of tone lines. 20II, I6, I09-II8.

Loos, Helmut: Das Monodram „Sophonisbe“ von Christian Gottlob Neefe. 2005, 5, 105-II 4 .

Škulj, Edo: Gallusovo obravnavanje mašnega ordinarija. 2005, 5, 229-248. 
Golobič, Špela: Odziv učiteljev in učencev na simfonično matinejo Glasbene mladine Slovenije. The response of teachers and pupils to a musical youth of Slovenia's symphony matinee. 20I 4, 20, 7I-92.

Golobič, Špela: Kulturna vzgoja na področju glasbene umetnosti v osrednjih slovenskih glasbenih institucijah. Cultural education in the field of music in Slovenian principal musical foundations. 2019, 31, I45-160.

Novak, Katja: Odnos mladih do klasične glasbe. Young people’s attitude to classical music concerts. 20I8, 28, 6I-78.

\section{Ucitelji glasbe/Music teachers}

Habe, Katarina: Osebnostne vrline in občutek poslanstva glasbenih pedagogov - temelj uspešne poklicne kariere glasbenega pedagoga. Character virtues and experiencing profession as a calling in music educators - A core of succesful music teaching. 2017, 27, 77-93.

Habe, Katarina: Študentski inovativni projekti (ŠIPK) - oblika neformalnega pridobivanja poklicnih kompetenc na visokošolski ravni. Students' inovative projects (ŠIPK) - A form of non-formal acquisition of professional competences at higher education. 2019, 31, 5-15.

Niermann, Franz, Hennessy, Sarah, de Vugt, Adri, in Malmberg, Isolde: Projekt meNet in učni izidi pri izobraževanju učiteljev glasbe. The meNet project and the learning outcomes in music teacher training. 2008, 10, 7-24.

Rimkutè-Jankuvienè, Sandra, in Girdzijauskienè, Rūta: Kompetence učiteljev glasbe za spodbujanje glasbene ustvarjalnosti učencev $s$ pomočjo MCT. Music teacher's competences to foster pupils' musical creativity through MCT. 2018, 28, 79-93.

Rotar Pance, Branka: Struktura lika učitelja glasbe. 1997, 2, I 43-I50.

Rotar Pance, Branka: Raziskava motivacijske naravnanosti učiteljev za vzgojno-izobraževalno delo na področju glasbe. 2000, 3, 38-54.

Rotar Pance, Branka: Izobraževanje učiteljev glasbe v evropskih državah v projektu meNet. Music teacher training in European countries in the meNet project. 2008, I0, 25-39.

Šantl Zupan, Karolina: Pedagoško in umetniško delovanje učiteljev pihal. Pedagogical and artistic work of wind instrument teachers. 2016, 24, 57-7I.

Škojo, Tihana, in Jukić, Renata: Ocenjevanje pedagoških kompetenc učiteljev solfeggia. The assessment of pedagogical competences of solfeggio teachers. 2019, 31, 69-81.

\section{Vseživljenjsko učenje/Lifelong learning}

Sicherl-Kafol, Barbara, in Rotar Pance, Branka: Tečaj accompagnato spremljava na poti vseživljenjskega učenja. 2005, 5, I29-I48. 
Sicherl-Kafol, Barbara: Vseživljenjsko učenje v okviru projektnega dela meNet. Lifelong learning in the framework of project meNet. 2008, I0, $40-5$ I.

\section{Zborovstvo/Choralism}

Misson, Andrej: Razmislek o sodobnem slovenskem zborovstvu. Brief overview of contemporary choral music in Slovenia. 2018, 29, 135-144.

Schaumberger, Helmut: Ključne kompetence zborovodij za strokovno vodenje otroških in mladinskih pevskih zborov. How to sing professionally with children and adolescents. core competencies of children's and couth choir directors. 2018, 29, 123-133.

\section{Zgodovina glasbe/History of music}

Barbo, Matjaž: Prispevek k orisu življenja in dela F. J. B. Dusíka. 2005, 5, 5368.

Bohak, Tina: Profil igralca (pevca) na Slovenskem od konca i9. stoletja do druge svetovne vojne. Actor's (singer's) profile in Slovenia from the late $19^{\text {th }}$ century to the World War II. 2011, 16, 57-75.

Cigoj Krstulović, Nataša: Glasbena matica, ljudska pesem in percepcija glasbe na Slovenskem v drugi polovici 19. stoletja. 2005, 5, 69-82.

Dekleva, Igor: Prispevek k mozaiku srečanj dveh dežel: stiki med Slovenijo in Avstrijo. 1997, 2, 23-36.

Flisar Šauperl, Manja: Glasbena matica Maribor z vidika glasbenega izobraževanja. Glasbena Matica Maribor from the perspective of music education. 2016, 25, 75-102.

Koter, Darja: Vloga ljubljanskega Dramatičnega društva pri glasbenogledališkem izobraževanju v obdobju od I869 do I877. The role of Ljubljana Dramatic Society at the music theatre education in the period I869 to $1877.2016,25,25-40$

Krones, Harmunt: Zur Geschichte des arbeiter $=$ Gesangvereines Vorwärts in Laibach. 2005, 5, 95-104.

Kuret, Primož: Slovenska glasba po prvi svetovni vojni. Slovene music after WWI. 2007, 8, 7-I4.

Kuret, Primož: Bravničarjeva »Srečanja in spomini«. Bravničar’s "Meetings and Reminiscences". 2008, 9, 25-32.

Kuret, Primož: Die Reisetagebücher des Paolo Santonino (I485-1487). Popotni dnevnik Paola Santonina (I485-I 487). Ponatis objave iz l. 1999. 2015, 22, 17-24.

Kuret, Primož: Slowenische protestantische Gesangbücher im I6. Jahrhundert. Slovenske protestantske pesmarice 16. stoletja. Ponatis objave iz 1. 2006. 2015, 22, 25-48.

Kuret, Primož: Die Rolle und die Tätigkeit der Philharmonischen Gesellschaft in Ljubljana. Delovanje in vloga Filharmonične družbe v Ljubljani. Ponatis objave iz 1. 1990. 2015, 22, 49-59. 
Kuret, Primož: Der Archivalienbestand der Philharmonischen Gesellschaft in Laibach - Eine bedeutende Quelle zum slowenischen Musikleben im 19. und beginnenden 20. Jahrhundert. Arhivska zbirka Filharmonične družbe v Ljubljani - pomemben vir o glasbenem življenju na Slovenskem V 19. in na začetku 20. stoletja. Ponatis objave iz 1. 2007. 2015, 22, 60-70.

Kuret, Primož: Die Laibacher Philharmonische Gesellschaft und die Illyrischen Provinzen (1809-13). Ljubljanska Filharmonična družba in Ilirske province (I809-1813). Ponatis objave iz l. 1989. 2015, 22, 71-77.

Kuret, Primož: Joseph Haydns Sakralwerke in Programmen der Philharmonischen Gesellschaft zu Ljubljana (Laibach). Haydnova sakralna dela na sporedih ljubljanske Filharmonične družbe. Ponatis objave iz 1. 2002. 2015, 22, 78-92.

Kuret, Primož: Einige erhaltene Briefe im Archiv der Philharmonischen Gesellschaft in Laibach/Ljubljana.Nekaj ohranjenih pisem v arhivu ljubljanske Filharmonične družbe. Ponatis objave iz l. 2004. 2015, 22, 93-108.

Kuret, Primož: Großes Jubiläum der Philharmonischen Gesellschaft in Ljubljana (Laibach) im Jahre I902. Veliki jubilej ljubljanske Filharmonične družbe leta 1902. Ponatis objave iz 1. 2004. 2015, 22, 109II7.

Kuret, Primož: Mozart-Rezeption in Slowenien. Recepcija Mozartovih del na Slovenskem. Ponatis objave iz 1. 1997. 2015, 22, 119-124.

Kuret, Primož: Johann Gottfried Herder und die Slowenen. Johann Gottfried Herder in Slovenci. Ponatis objave iz 1. 2002. 2015, 22, I25-132.

Kuret, Primož: Das Ständische Theater in Ljubljana/Laibach: über die italienischen Opernaufführungen am Ende des I8. und Anfang des 19. Jahrhunderts in Ljubljana. Stanovsko gledališče v Ljubljani: italijanske operne predstave ob koncu I8. in na začetku 19. stoletja. Ponatis objave iz 1. 1999. 2015, 22, 133-I4I.

Kuret, Primož: Biedermeier in Slowenien. Bidermajer na Slovenskem. Ponatis objave iz 1. 2000. 2015, 22, I42-149.

Kuret, Primož: Zum Werdegang der slowenischen nationalen Musikkultur. $\mathrm{K}$ nastanku slovenske nacionalne glasbene kulture. Ponatis objave iz 1 . 1993. 2015, 22, 150-I54.

Kuret, Primož: Die geistliche Musik und die slowenische Nationalbewegung in der zweiten Hälfte des 19. Jahrhunderts. Duhovna glasba in slovensko narodno gibanje v 2. polovici 19. stoletja. Ponatis objave iz l. 1994. 2015, 22, 155-161.

Kuret, Primož: Mahler und Ljubljana/Laibach. Mahler v Ljubljani. Ponatis objave iz 1. 1989. 2015, 22, 162-169.

Kuret, Primož: Laibacher Orchesterverhältnisse und Mahler Orchesterbesetzung in Laibach. Ljubljanske orkestrske razmere in 
Mahlerjeva zasedba orkestra v Ljubljani. Ponatis objave iz 1. 1998. 2015, 22, 170-I83.

Kuret, Primož: Die slowenish-tschechischen Musikbeziehungen und Antonín Dvořák. Slovensko-češki glasbeni stiki in Antonin Dvořák. Ponatis objave iz 1. 2007. 2015, 22, 184-190.

Kuret, Primož: Ein Brief des slowenischen Komponisten Benjamin Ipavec an Leoš Janáček. Pismo slovenskega skladatelja Benjamina Ipavca Leošu Janáčku. Ponatis objave iz 1. 2001. 2015, 22, 191-195.

Kuret, Primož: „Alle Landschaft ist ein Seelenzustandt...“: Hugo Wolf seine Zeitgenossen und Nachfolger. »Vsa pokrajina je odraz duše ...«: Hugo Wolf - njegovi sodobniki in nasledniki. Ponatis objave iz 1. 200 I. 2015, 22, 196-203.

Kuret, Primož: Zemlinsky als Lehrer des slowenischen Komponisten Josip Ipavec. Zemlinsky - učitelj slovenskega skladatelja Josipa Ipavca. Ponatis objave iz 1. 1995. 2015, 22, 204-208.

Kuret, Primož: Die Arbeiterkultur in Laibach während der k. k. Monarchie. Kultura delavskega razreda v Ljubljani v času Monarhije. Ponatis objave iz 1. 1999. 2015, 22, 209-218.

Kuret, Primož: Die Musik am Anfang des 20. Jahrhunderts in den Kirchen Ljubljanas. Glasba v ljubljanskih cerkvah na začetku 20. stoletja. Ponatis objave iz 1. 2006. 2015, 22, 219-227.

Kuret, Primož: Militärmusikkapellen in Ljubljana. Vojaške godbe v Ljubljani. Ponatis objave iz 1. 2004. 2015, 22, 228-235.

Kuret, Primož: Deutsches Kulturschaffen in Krain vor dem Ersten Weltkrieg. Nemška kultura na Kranjskem pred prvo svetovno vojno. Ponatis objave iz 1. 1992. 2015, 22, 236-244.

Kuret, Primož: Wagner in den Konzert - und Opernprogrammen vor dem Ersten Weltkrieg in Ljubljana/Laibach. Wagner na ljubljanskih koncertnih in opernih sporedih pred prvo svetovno vojno. Ponatis objave iz 1. 2013. 2015, 22, 245-253.

Kuret, Primož: Wien und Slowenien - gegenseitige Bereicherungen. Dunaj in Slovenija - medsebojna obogatitev. Ponatis objave iz 1. 2009. 2015, 22, 254-267.

Kuret, Primož: Sloweniens Schicksal 1918-1991: Eine kulturhistorische Skizze. Usoda Slovenije I918-I991: kulturnozgodovinska skica. Ponatis objave iz 1. 1992. 2015, 22, 268-273.

Kuret, Primož: Slavko Osterc - Minutenopern. Slavko Osterc - minutne opera. Ponatis objave iz 1. 2005. 2015, 22, 274-278.

Kuret, Primož: Zwei verschiedene „Pater noster“ von Slavko Osterc und Karol Pahor. Dva različna očenaša, Slavka Osterca in Karola Pahorja. Ponatis objave iz 1. 2007. 2015, 22, 279-283. 
Kuret, Primož: Die Bedeutung der Musik in der slowenischen Widerstandsbewegung. Pomen glasbe v slovenskem odporniškem gibanju. Ponatis objave iz 1. 2004. 2015, 22, 284-289.

Kuret, Primož: Slowenische Musik der soer und 6oer Jahre. Slovenska glasba 50. in 60. let. Ponatis objave iz l. 1998. 2015, 22, 290-294.

Kuret, Primož: Slowenische Musik heute zwischen Staat und Markt. Slovenska glasba danes - med državo in tržiščem. Ponatis objave iz l. 2000. 2015, 22, 295-300.

Kuret, Primož: Musik als Opposition. Glasba kot opozicija. Ponatis objave iz 1. 1995. 2015, 22, 301-305.

Kuret, Primož: Das apokalyptische Jahrhundert. Apokaliptično stoletje. Ponatis objave iz 1. 2000. 2015, 22, 306-311.

Sivec, Jože: Italijanske operne družbe na odru ljubljanskega gledališča v obdobju romantike. 1997, 2, 49-66.

Sivec, Jože: Aufstieg und Untergang der deutschen Oper im Ständischen Theater zu Ljubljana (Laibach) in den zoer und 4oer Jahren des 19. Jahrhunderts. 2005, 5, I 49-172.

Snoj, Jurij: Notacijska podoba gregorijanskega korala v srednji Evropi. 2005, 5, 173-192.

Šarec, Veronika: Vloga glasbe v taborskem gibanju na Slovenskem v letih od I868 do I87I. The role of music in the mass movement in Slovenia between year I868 and I87I. 2010, I4, 89-115.

\section{Zgodovina glasbene pedagogike/History of musical pedagogy}

Bohak, Tina: Solopevska pedagogika na glasbeni šoli društva Glasbena matica od začetkov do ustanovitve konservatorija (1882-1919). Solo singing pedagogy in Glasbena matica music school from its beginnings to establishment of conservatory (I882-1919). 2016, 25, 57-73.

Cigoj Krstulović, Nataša: Načela in podobe slovenskega javnega glasbenega izobraževanja: primer šole in konservatorija ljubljanske Glasbene matice (1882-1926). Principles and forms of Slovenian public music education: The case of Glasbena matica music school and conservatory in Ljubljana (1882-1926). 2016, 25, 4I-55.

Ivec, Anja: Glasbena revija kot učilo: Mlada Sloga, glasilo glasbene šole Sloga v Ljubljani. Music magazine as a teaching aid: Mlada Sloga, publication of the Sloga music school in Ljubljana. 2019, 31, 169-180.

Košta, Tomislav: Razvoj predmeta petje v osnovnošolskih programih Hrvaške in Slovenije v obdobju med svetovnima vojnama. Development of singing lessons in elementary school curricula in Croatia and Slovenia in interwar period. 2010, I 4, 7 I-88.

Koter, Darja: Vzgojno-izobraževalno in kulturno poslanstvo ljubljanske Glasbene matice in Glasbene akademije v letih 1939-1945. The 
educational and cultural mission of the Glasbena matica Ljubljana music society and Academy of Music 1939 to 1945. 2013, 19, 6I-74.

Oblak, Breda: Narativni izraz poti skozi glasbeno šolstvo. Narrative expression of path through musical education. 2016, 25, 9-24.

Rauter, Branislav: Zgodovinski vpogled v pouk kitare v slovenskem glasbenem šolstvu. Historical insight into guitar lessons in Slovenian music education. 2016, 25, 103-127. 